\title{
IRON-COATED PARTICLES FROM CONDENSED AALENIAN-BAJOCIAN DEPOSITS: EVOLUTIONARY MODEL (IBERIAN BASIN, SPAIN)
}

\author{
ALEJANDRA GARCÍA-FRANK, ${ }^{1}$ SOLEDAD URETA, ${ }^{1}$ AND RAMÓN MAS ${ }^{2}$ \\ ${ }^{1}$ Departamento de Paleontología, Facultad C.C. Geológicas, Universidad Complutense de Madrid, Cl José Antonio Nováis 12 , C.P. 28040 Madrid, Spain \\ ${ }^{2}$ Departamento de Estratigrafia and Instituto de Geociencias (CSIC-UCM), Facultad C.C. Geológicas, Cl José Antonio Nováis 12, C.P. 28040 Madrid, Spain \\ e-mail: agfrank@geo.ucm.es
}

\begin{abstract}
Condensed intervals provide a framework to study evolution of iron-coated particles. This study examines the ironrich particles contained in the condensed carbonate deposits spanning from uppermost Toarcian to lower Bajocian in the northwestern Iberian Range (northern Spain), to unravel the controls on geochemical changes in the basin by determining variation in mineralogy and REY (rare earth elements and yttrium) as potential predictors of provenance. The particles are composed mostly of the ferrous phyllosilicate berthierine, and by Fe-oxyhydroxide goethite. Depositionally, iron-rich particles occur at specific horizons, and display changes in character, from iron cortoids (Stage 1) in lowest Aalenian sediments, passing to small-sized iron ooids (Stage 2) in early Aalenian strata and to more complex iron-grain aggregates and larger iron ooidoncoid mixed particles (Stage 3) in the middle-upper Aalenian succession. In the lower Bajocian sediments that represent the most condensed interval, diagenetic processes strongly affected previously iron-coated particles.

The genesis of the diverse suite of iron-rich particles is explained by petrographic and mineralogic studies revealing oscillation in redox conditions. Berthierine genesis is linked with suboxic conditions below the water-sediment interface. Subsequent periods of low rates of sediment accumulation allowed the exhumation of particles, and exposing them to oxic conditions that favored goethite formation. Definitive burial led to the development of isopachous circumgranular berthierinic cement rims and dissolution and replacement.

Studies of REY and comparison with iron-rich samples of diverse provenance suggest a conceptual model for geochemical evolution of these deposits. The lack of both contemporaneous soil deposits and evidence of subaerial exposure in this arid paleoclimatic setting rule out weathering processes as the main source of iron. Instead, geochemical indexes (Y/Nb and Y/La ratios) suggest that coeval Iberian volcanism was the most plausible iron source.

The sedimentological, mineralogical, and chemical attributes of these iron deposits provides proxies to interpret redox and geochemical fluctuations and integrate all the data in an evolutionary model. Variations in REY patterns offer a framework for correlation at both local and subregional scales. Likewise, as this study provides new geochemical data for the Aalenian period, including the Fuentelsaz GSSP worldwide reference section, it enhances knowledge of the evolution of the westernmost Tethyan basins and the significance of widely distributed oolitic ironstones. The data collectively reveal how the REY signature of condensed sediments can be used to obtain detailed information on the geochemical and paleoceanographic conditions of depositional basins.
\end{abstract}

\section{INTRODUCTION}

Unconformities, hiatal surfaces, and condensed units have been noted frequently in studies of oolitic ironstones worldwide. Ferruginous particles, and associated unconformities and condensed sections, may provide important information for analyzing the evolution of the particles and interpreting the source of iron and the causes of their formation, and moreover, they can record paleoceanographic information. In parts of the NW Iberian Range, the Aalenian to Bajocian (Jurassic) interval, which includes condensed marine carbonate strata characterized by the presence of hardgrounds, oolitic ironstones, and hiatuses of variable extent (Goy and Ureta 1990; García-Frank 2007; García-Frank et al. 2006, 2008), provides a unique opportunity to examine the record and formative processes of ferruginous particles. Specifically, this succession can provide insights into three aspects of the genesis of oolitic ironstones that have been controversial topics for decades: (1) the source of iron; (2) the peculiar mineralogy of the particles, and (3) the sedimentary environment where the particles formed.

With regards to the source of iron, two broad categories of hypotheses have been invoked to explain the source of iron in the Fe minerals. These sources of iron could be a product of chemical weathering of soils or marine sediments, or related to exhalative processes.

Likewise, considering the formation of the iron minerals, the most common mineralogies of ironstones include phyllosilicates (berthierine, chamosite) and oxyhydroxides (goethite), associated with carbonates (siderite) or sulfides (pyrite), and with non-Fe minerals such as phosphates (apatite). Diagenetic and metamorphic reactions change the mineralogy of iron particles, such that chamosite is thought to be the stable phase of berthierine at temperatures over $80{ }^{\circ} \mathrm{C}$ (Velde 1995; Meunier 2005); debate about the nomenclature of the serpentine family 


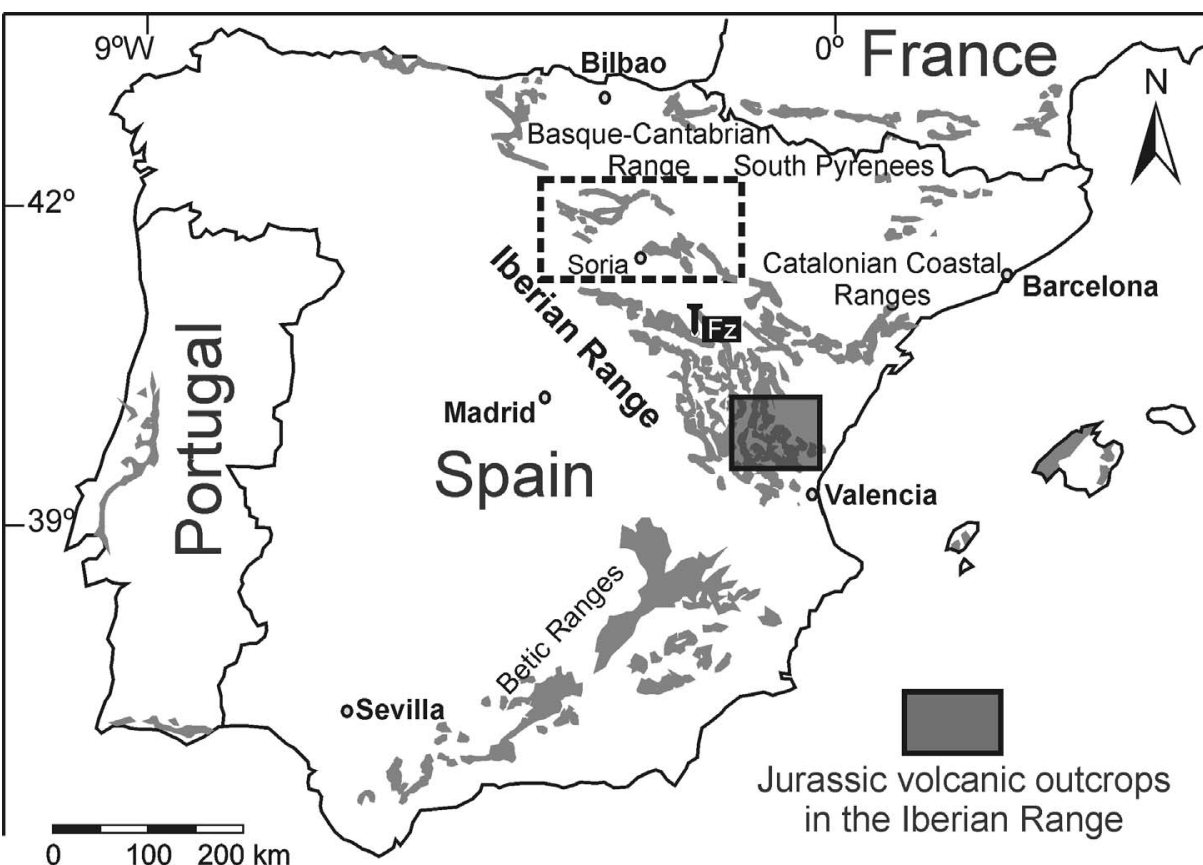

FIG. 1.- Jurassic outcrops in the Iberian Peninsula (shown in gray) with the location of the study area (dashed rectangle) and the Fuentelsaz GSSP for the Toarcian-Aalenian boundary. The squared gray area in the south eastern part of the Iberian Range shows the location of Jurassic alkaline volcanism, mainly volcaniclastic deposits. (berthierine-odinite) is not a concern of this paper. The diverse hypotheses about the genesis of berthierine, the main Fe mineral in ironstones, are linked closely with discussions of the source of iron. Some authors relate its formation to weathering (see Young and Taylor 1989; Needham et al. 2004, 2005, and references therein), whereas others propose an exhalative origin including tecto-magmatic regimes (Dreesen 1989), pure volcanic origin (Sturesson 1992, 2003; Sturesson et al. 2000), deep magmatic sources (Kimberley 1989, 1994, 2005) or precipitation in a marine environment linked to sedimentary exhalative hydrothermal processes (Rivas-Sanchez et al. 2006). Some authors suggest that berthierine is an early diagenetic mineral, since at times of low net sediment accumulation rates, non-sulfidic post-oxic diagenesis (Berner 1981) dominates (e.g., Spears 1989; Young 1989; Taylor and Curtis 1995; Taylor 1998). To complicate matters, these conceptual models of berthierine formation may not be mutually exclusive (e.g., Young 1989; Reolid et al. 2008).

The interpretations of a third topic of debate, the ancient depositional settings of the iron particles, are varied (see Kimberley 1978), in part because analogous modern iron particles are scarce. Modern berthierinecoated particles occur in Indonesia (Heikoop et al. 1996) in a volcanic context, and on the coast of Venezuela (Kimberley 1994, 2005) associated with active faults related to gas exhalation.

To address these questions concerning the source of iron, the peculiar mineralogy of the particles, and the sedimentary setting where they form, this study describes new sedimentological, petrographical, and geochemical data from ironstones from the condensed Early-Middle Jurassic transition in the NW Iberian Range. In this context, the purpose of this study is to review and compare relationships among petrographic character, geochemical signature, and sedimentological patterns within and among a suite of iron-coated particles generated in diverse contexts. These observations and comparisons illustrate the nature and origin of depositional and diagenetic themes and motifs within iron-rich particles. The systematic examination of the details of chemistry of iron-coated particles provides new insights into the formation of oolitic ironstones in condensed sediments, motivating a new conceptual model for the longstanding conundrum concerning the genesis of these geologically important particles. The specific aims of this study are: 1) to unravel the depositional and diagenetic controls in the basin by determining the variation in mineralogy and bulk geochemistry in sediments of different stratigraphic and paleogeographic settings, as a potential predictor of provenance; 2) to evaluate the relative importance of volcanism and weathering processes as sources of reactive $\mathrm{Fe}$ for the iron-coated particles; 3) to determine whether changes in sedimentation rate resulted in formation of particular Fe-coated particles, which in turn record paleoceanographic information of Jurassic seawater.

\section{GEOLOGICAL SETTING}

The NW-SE-trending Iberian Range is an intracontinental Alpine foldand-thrust belt, about $600 \mathrm{~km}$ long, that includes both Variscan basement and the Mesozoic cover, and shows a double vergence (Mas et al. 2003; Guimerá et al. 2004). The range developed through the Paleogene and Miocene through tectonic inversion of the Mesozoic Iberian Rift System (e.g., Salas et al. 2001). The study area is located in the northwestern extreme of the Iberian Range (Figs. 1, 2). On the basis of facies, thickness, and fossil content of the uppermost Toarcian to lowermost Bajocian sediments, García-Frank et al. (2008) distinguished four main areas (Fig. 2), informally noted as Demanda (NW), San Leonardo (SW), Madero-Moncayo (SE), and Cameros (NE).

The early Middle Jurassic (Aalenian-lowermost Bajocian) sedimentary record of the NW part of the Iberian Basin was affected by synsedimentary tectonics, generating two major facies domains: Iberian Basin domain (IB domain) including the Demanda, San Leonardo and Madero-Moncayo areas, and Basque-Cantabrian Basin domain (BCB domain) represented by the Cameros area. Iron-coated particles occur only in the IB domain (Fig. 2). Two main episodes of faulting affected both the IB domain and the $\mathrm{BCB}$ domain during the Early-Middle Jurassic transition (García-Frank et al. 2008), caused by synsedimentary faulting due to extensional tectonics in this period. This faulting is associated with development of widespread unconformities in several Iberian and western European basins (e.g., Basque-Cantabrian and Asturias basins: Aurell et al. 2003; Betic Cordillera: Azañón et al. 2002; Algarve Basin: Terrinha et al. 2002; Lusitanian Basin: Wright and Wilson 1984; Aquitaine Basin: Lezin et al. 2007; Swiss Jura and adjacent areas of 


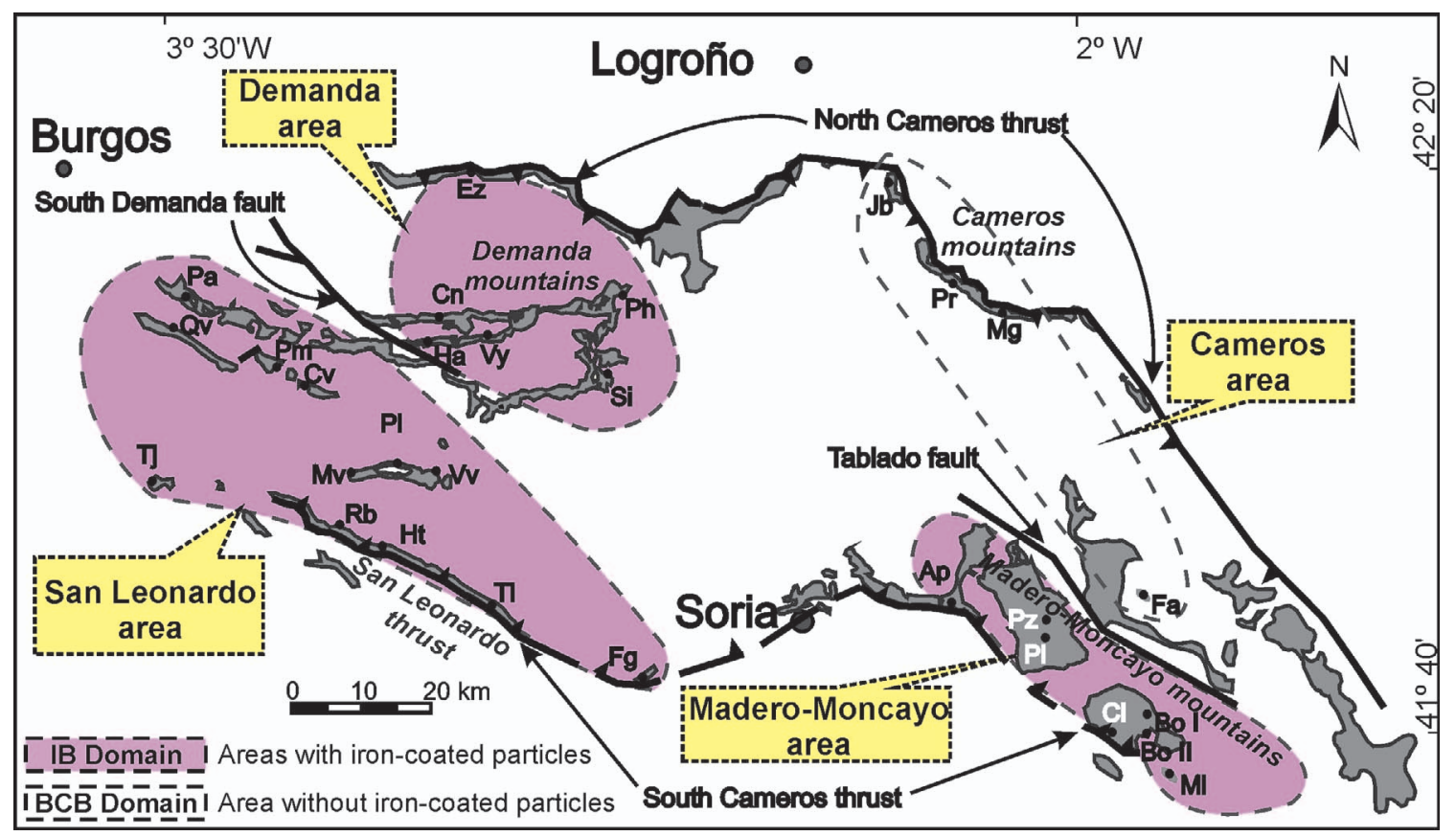

Fig. 2.-Location of the studied sections, the tectonic structures, and the four major areas defined in the Northwestern Iberian Range during the Aalenian (after García-Frank 2007; García-Frank et al. 2008). The shaded areas include the sections with Toarcian, Aalenian, and Bajocian iron-coated particles. Abbreviations of sections: Demanda area: Canales de la Sierra (Cn), Ezcaray (Ez), Huerta de Arriba (Ha), Peñahincada (Ph), Santa Inés (Si), Villavelayo (Vy); San Leonardo area: Castrovido (Cv), Hontoria del Pinar (Ht), Las Fraguas (Fg), Moncalvillo (Mv), Paules de Lara (Pa), Palacios de la Sierra (Pl), Piedrahita de Muñó (Pm), Quintanilla de las Viñas (Qv), Rabanera del Pinar (Rb), Tejada (Tj), Talveila (Tl), Vilviestre del Pinar (Vv); Madero-Moncayo area: Aldealpozo (Ap), Borobia I (Bo I), Borobia II (Bo II), Ciria (Ci), Malanquilla (Ml), Pinilla del Campo (Pi), Pozalmuro (Pz); Cameros area: Fuentes de Ágreda (Fa), Jubera (Jb), Muro de Aguas (Mg) and Préjano (Pr).

SW Germany: Wetzel et al. 2003; western Middle Atlas: El Hammichi et al. 2002).

In this framework, in the SE sector of the Iberian Basin (Fig. 1) the early Toarcian to early Bajocian included multiple episodes of alkaline volcanism, recorded mainly by volcaniclastic deposits, and subordinate basaltic sills (Gautier and Odin 1983; Fernández-López et al. 1985; Martínez-González et al. 1997; Lago et al. 2004; and references therein). Early to Middle Jurassic magmatic activity has also been reported from other Iberian basins (middle Subbetic: e.g., Martín-Algarra et al. 2004; Algarve Basin: Pinheiro et al. 1996), and evidence of widespread basaltic volcanism, thermal doming, and collapse have been documented in the North Sea region (e.g., Underhill and Partington 1993; Hesselbo and Jenkyns 1998; Ziegler 2004). All these magmatic episodes set an imprint in coeval sedimentary materials, which may also be recorded through the carbonate deposits and embedded iron-coated particles.

Condensed levels, characterized by the presence of hardgrounds and biostratigraphically defined hiatuses of variable duration, have been cited frequently in regional studies concerned with Iberian late-Early Jurassic to early-Middle Jurassic strata. Facies characteristics in AalenianBajocian deposits from the NW Iberian Range suggest condensed sections (Goy and Ureta 1990), with low sedimentation rate and prolonged submarine exposure (García-Frank 2007; García-Frank et al. 2008).

Five third-order stratigraphic sequences (sensu Vail et al. 1991), coincident with five transgressive-regressive cycles (S1 to S5) and bounded by five unconformities (U1 to U5), were identified between the Upper Toarcian and the lowermost Bajocian by García-Frank et al. (2008) in the IB domain (Fig. 3A). Cyclicity is different in the Cameros area (BCB domain), where twelve stratigraphic sequences were identified in this interval (Fig. 3A). A characteristic of the youngest IB domain sequences (S3, S4, and S5) is low net accumulation rates (estimated at
$0.65,0.7$, and $0.45 \mathrm{~m} / \mathrm{Myr}$ respectively) relative to the coeval $\mathrm{BCB}$ domain sequences (ranging between 5.08 and $19.44 \mathrm{~m} / \mathrm{Myr}$; see García-Frank et al. 2008). Here, in the IB domain, iron-coated particles are found, associated mostly with areas and intervals of condensed sedimentation (elevated fault blocks resulting from the intermittent extensional tectonics; GarcíaFrank et al. 2008).

Lithostratigraphically, in the IB domain, the Turmiel, Casinos, and El Pedregal formations (Gómez et al. 2003; Gómez and Fernández-López 2004) consist of limestone and marl (Fig. 3B). An alternation of mudstone to wackestone-limestone and marl occurs in the Turmiel Formation; the Casinos Formation is limestone with variable bioclastic content and thin marl interbeds, and the El Pedregal Formation is fossilpoor wackestone. Iron-coated particles occur in the uppermost limestone unit of the Turmiel Formation and in variable positions within the Casinos Formation (Fig. 3C). There is no evidence of iron-coated particles in the rhythmic alternation of organic-rich dark gray marls and mudstone to wackestone of the Castillo Pedroso Formation at the BCB domain (Cameros area), or within the Aalenian GSSP of Fuentelsaz (Cresta et al. 2001), where due to erosion only S1 and S2 are preserved (Fig. 3A, B, C).

\section{MATERIAL AND METHODS}

This study includes a detailed petrographic and geochemical description of the different types of $\mathrm{Fe}$ particles found in the carbonate deposits. It also includes data from the Aalenian GSSP of Fuentelsaz, located in the Castilian Branch of the Iberian Range, which was situated in a more proximal setting than the rest of the studied sections of the NW Iberian Range, to compare the coeval materials.

One hundred and sixty samples of iron-rich particles, ranging in age from upper Toarcian to lower Bajocian, were collected from 21 outcrops 

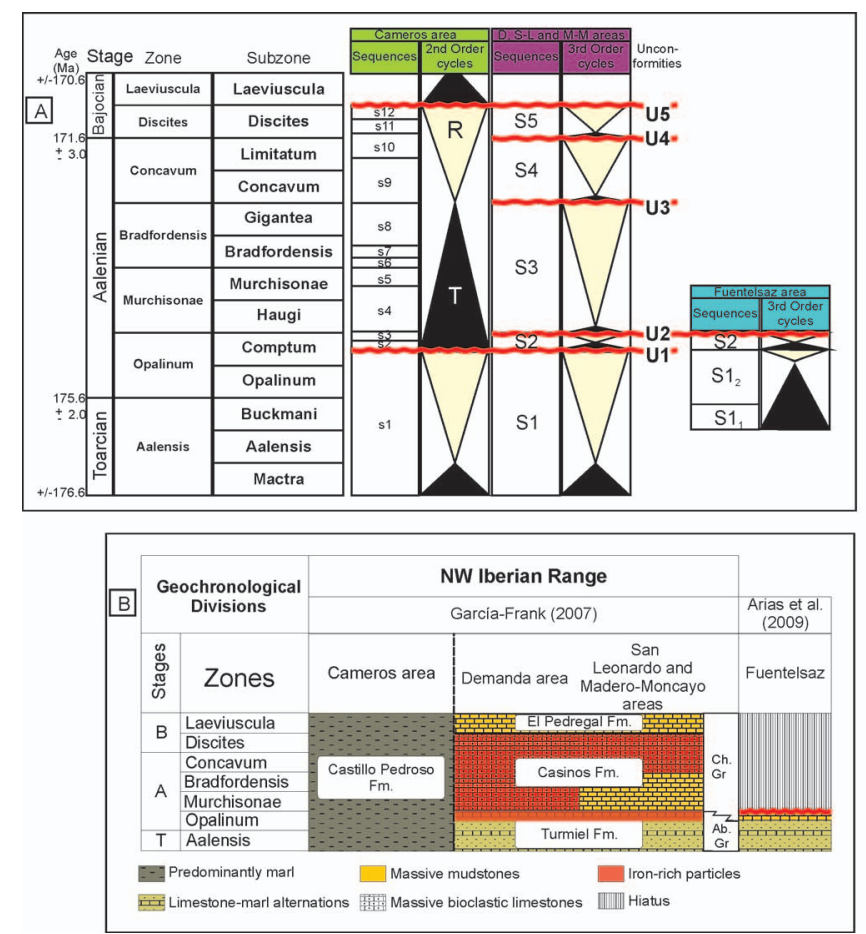

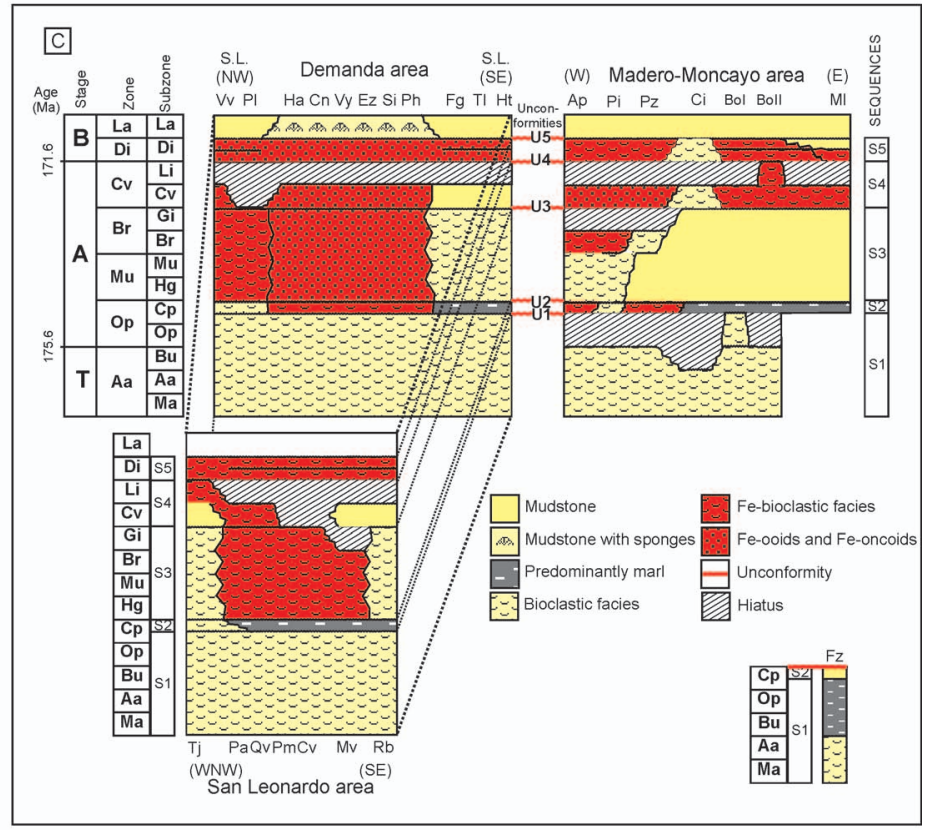

FIG. 3.-A) Sequence, T-R cycles, and B) unconformities distribution and lithostratigraphic scheme of the NW Iberian Range and Fuentelsaz GSSP. C) Iron-coated particles appear in the Demanda, San Leonardo, and Madero-Moncayo areas (IB domain). Absolute ages are from Gradstein and Ogg (2004). Biostratigraphic scale is from Henriques et al. (1996). Sequences, T-R cycles, and unconformities are from García-Frank (2007); García-Frank et al. (2008), and Arias et al. (2009). Abbreviations: T, Toarcian; A, Aalenian; B, Bajocian; Ab. Gr, Ablanquejo Group; Ch. Gr, Chelva Group. For abbreviations for sections, see Figure 2.

within the IB domain (Fig. 2). The state of weathering of the outcrops was carefully checked since Fe minerals are highly susceptible to this process, and sampling avoided surficial parts of rocks. The bed-by-bed description of the stratigraphic sections, supplemented by the precise ammonite biostratigraphy, reveals details of the accumulation history of condensed deposits and their iron-rich components. Study of 525 successive ammonoid assemblages (ammonoid biostratigraphic scale of Henriques et al. 1996; Sandoval et al. 2001) within all the sections refines the chronostratigraphic range of the sequences and their boundaries with a precision of approximately 0.5 Ma. (García-Frank 2007; García-Frank et al. 2008).

Polished thin sections were made of the 160 samples and studied by transmitted-light microscopy. A subset of 10 samples was coated with carbon for morphometric study using back-scattered images in a Jeol 6400 scanning electron microscope (SEM) at Centro de Microscopía Electrónica Luis Bru, Universidad Complutense de Madrid. Some ironcoated particles were mechanically separated from the rock, mounted in stubs, coated with gold, and studied by secondary electron images in the SEM, to see the three-dimensional development of coatings. The mineralogy of the iron-coated particles from 16 samples was determined by X-ray diffractometry (XRD) on a Siemens Kristalloflex 810 X-ray diffractometer using $\mathrm{Cu}-\mathrm{K} \alpha$ radiation at $40 \mathrm{kV}$ and $30 \mathrm{~mA}$, a step size of $0.03^{\circ} 2 \theta$, and time per step of $1 \mathrm{~s}$ (Universidad Complutense de Madrid, Departamento de Cristalografía y Mineralogía). Diffraction peak heights for berthierine and goethite correspond well with relative abundances visually estimated in thin section, matching the quantitative mineralogical analyses performed on bulk rocks in the study area (García-Frank, 2007).

Five samples containing abundant iron-coated particles and six selected samples from the Aalenian GSSP at Fuentelsaz, including limestones and marls, were mechanically crushed in an agate mortar and pestle for geochemical analysis. Determinations for REY (rare earth elements + yttrium; Y inserted between Dy and Ho according to its ionic radius) were made by inductively coupled mass spectrometry (ICP-MS) at Activation Laboratories (Canada) using a Perkin-Elmer SCIEX ELAN 6000 ICPMS instrument, a lithium metaborate/tetraborate fusion ICP traceelement Code 4Litho. The iron-coated samples included 10 standards for the analyses, and the Fuentelsaz samples included 16 standards (detection limits are shown in Table 2). Results are plotted relative to Chondrite (Taylor and McLennan 1985) and PAAS (McLennan 1989). The parameters to describe REY distribution patterns were adopted from Haley et al. (2004).

To detect affinities in the studied iron-coated particles trends, they are also compared with other samples from (1) the PAAS (Taylor and McLennan 1985), (2) iron ooids, including (2a) present-day iron ooids from Indonesia (Sturesson et al. 2000) and (2b) Oxfordian iron ooids (type A iron ooids from Reolid et al. 2008), (3) iron lateritic crusts from the Betic Cordillera (Reolid et al. 2008), (4) carbonates (limestones and marls) lacking these particles at the Aalenian GSSP at Fuentelsaz (this study), and (5) present-day seawater (Zhang and Nozaki 1996). A discrimination between light-REE (LREE; La, Ce, Pr, and Nd), middleREE (MREE; Eu, Gd, Tb, and Dy), and heavy-REE (HREE; Er, Tm, $\mathrm{Yb}$, and $\mathrm{Lu}$ ) are plotted together with $\mathrm{Sm}, \mathrm{Ho}$, and $\mathrm{Y}$.

\section{RESULTS}

\section{Iron-Coated Particles}

The particles from the NW Iberian Range consist of iron-skeletal grains, iron-coated grains (cortoids, ooids, and oncoids) and iron-grain aggregates (terminology of Flügel 2004), composed mostly of the ferrous phyllosilicate berthierine, and in lesser abundance, the iron oxyhydroxide goethite (see Fig. 4, with the X-ray diffraction patterns of the minerals in 


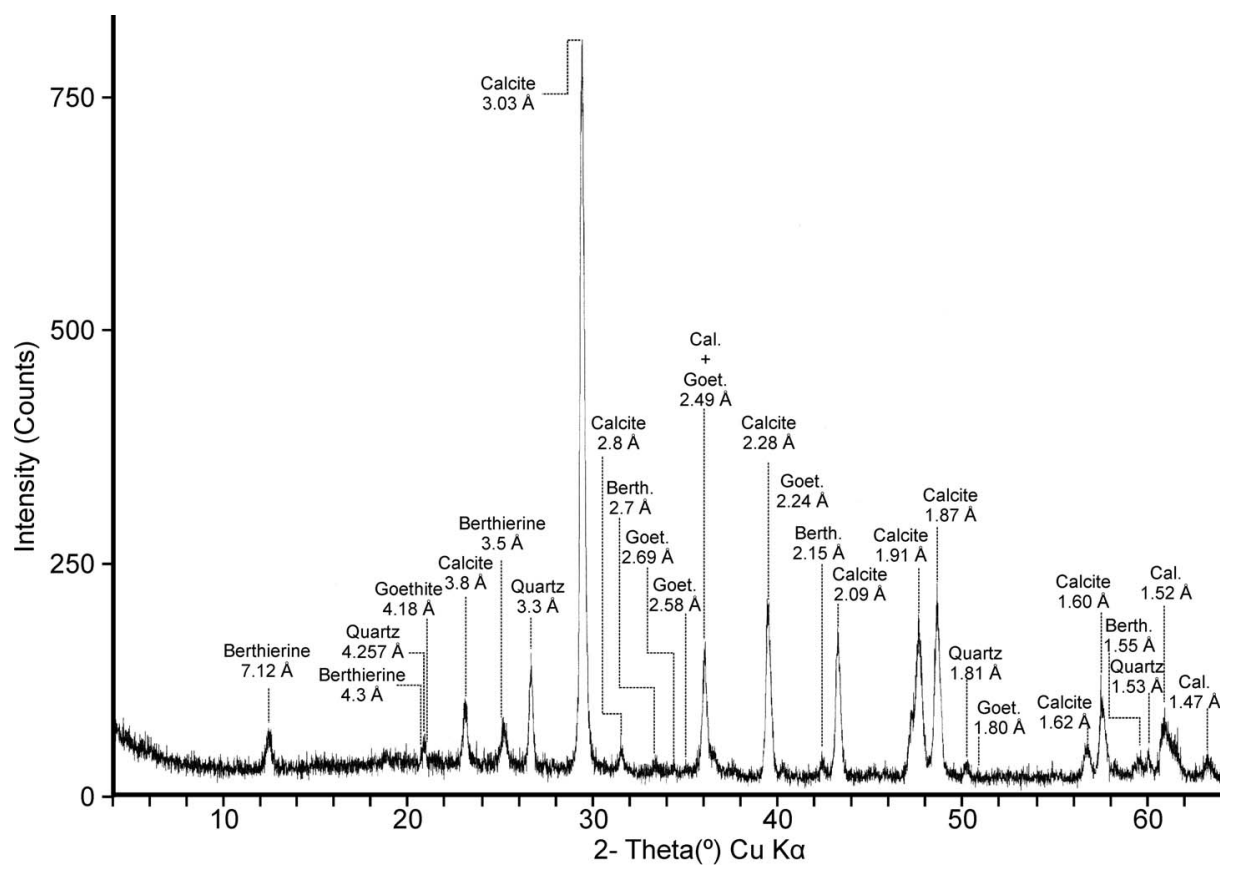

FIG. 4.-X-ray diffraction pattern of a "type sample" (Ha-54; Discites Z.). The main mineral reflections are calcite (Cal.), berthierine (Berth.), quartz, and goethite (Goet.). the most common iron-coated particles). Calcite from calcareous fossils or intraclasts forms the nuclei of the particles, whereas berthierine and goethite occur in the outer coatings. Locally, pyrite occurs inside foraminiferal tests. Subordinate quartz is also present.

Petrographic and SEM analyses of iron-coated particles reveal three stages of depositional development and two stages of diagenetic modification (Figs. 5-7; Table 1). These stages include a variety of processes.

Stage 1.-Initial pre-existing particles, mainly carbonate grains such as peloids, cortoids, or skeletal grains, show preferentially enhanced ferruginization (Fig. 5A, B). These iron-rich skeletal grains without coatings are mostly fossils (microfossils or fragments of larger skeletons), including porcellaneous, agglutinated, and hyaline foraminifera (chamber infillings and tests), echinoderms (plates), and bryozoans. Iron micronodules or iron intraclasts are present locally (e.g., see lower left area in Fig. 6G). Generally, Stage 1 particles are smaller than $0.5 \mathrm{~mm}$, poorly sorted, and have low sphericity and roundness (see Table 1).

Stage 2.-Particles show more complexity than Stage 1 particles, due to the development of between two and seven regular coatings or laminae around the nucleus. These particles, with both a nucleus and defined laminations, are true iron ooids (Fig. 5C-E). The mineralogy of the coatings is mainly berthierine, which under SEM consists of platy crystallites (Fig. 6B). Locally, coatings with brown to red color appear interlayered with the green berthierine laminae, suggesting the precipitation of goethite or another oxidized mineralogy of iron. Encrusters (foraminifera, serpulids, and bryozoans) are interlayered with the coatings. Nuclei of these particles commonly include grains modified during Stage 1, but these can amalgamate, forming polynucleous particles (see Fig. 6E, F). Particles formed in Stage 2 have sizes less than $0.8 \mathrm{~mm}$, are poorly to well sorted, and subrounded to ellipsoidal (Table 1).

Stage 3.-This stage is recognized by the formation of irregular iron coatings, commonly associated with encrusters. Individual laminae show variable thickness, making oncoid-like features due to their irregular coating pattern (Fig. 5F-H). These particles are similar to Oxfordian type
B ooids of Reolid et al. (2008). Irregular layers can occur interlaminated with ooid-like regular ones, suggesting alternate episodes of formation (Fig. 5G, H). The associated encrusting organisms include hyaline, porcellaneous, and agglutinated foraminifera, bryozoans, serpulids, and possibly, cyanobacteria (see Figs. 5F, H, 6D). Commonly, they are mineralized (filled or replaced) by iron oxyhydroxide, such as goethite (Fig. 6C). These particles, with a nucleus covered with irregular layers, are described here as iron oncoids and correspond to foraminiferal oncoids (dominating encrusting foraminifera such as Nubecularia) and composite oncoids (with foraminifera or bryozoans, or other encrusting organisms) (following the classification of Flügel 2004, p. 123).

Composite particles or aggregate grains (grapestones or lumps) are formed by other grains bound together by organic films, encrusting organisms, and cements (Flügel 2004). Partially ferruginized aggregate grains appear to be associated with iron oncoids in the samples (Fig. 6G). These iron-grain aggregates are not totally ferruginized, or ferruginization is variable. The size of the particles commonly is greater than $1 \mathrm{~mm}$ (see Table 1). Aggregated particles include large fossil fragments, encrusters such as serpulids and bryozoans, and partially ferruginized lithoclasts, and commonly are enclosed in a dark brown matrix.

Diagenetic Phase A.-Diagenetic phase A within iron particles corresponds to the formation of an isopachous circumgranular bladed to dog-tooth cement partially to totally covering iron-coated particles. The most common mineral composing the cement is berthierine (Fig. 7A). Locally berthierine coexists with calcite. Crystals of both mineralogies are up to $10 \mu \mathrm{m}$ wide, and vary between 50 and $100 \mu \mathrm{m}$ in length (see Table 1). This stage is not recognized in every geographical region. Analogously, they show variable development; in some cases particles in the same stratigraphic level include a rim around them, whereas other particles have no rim.

Diagenetic Phase B.-This phase corresponds to relic textures of ironrich particles (ghost particles) that resemble former iron particles (Fig. 7B). Frequently, undissolved residual iron minerals, such as goethite or pyrite, remain within the ghost particle (see Table 1). 

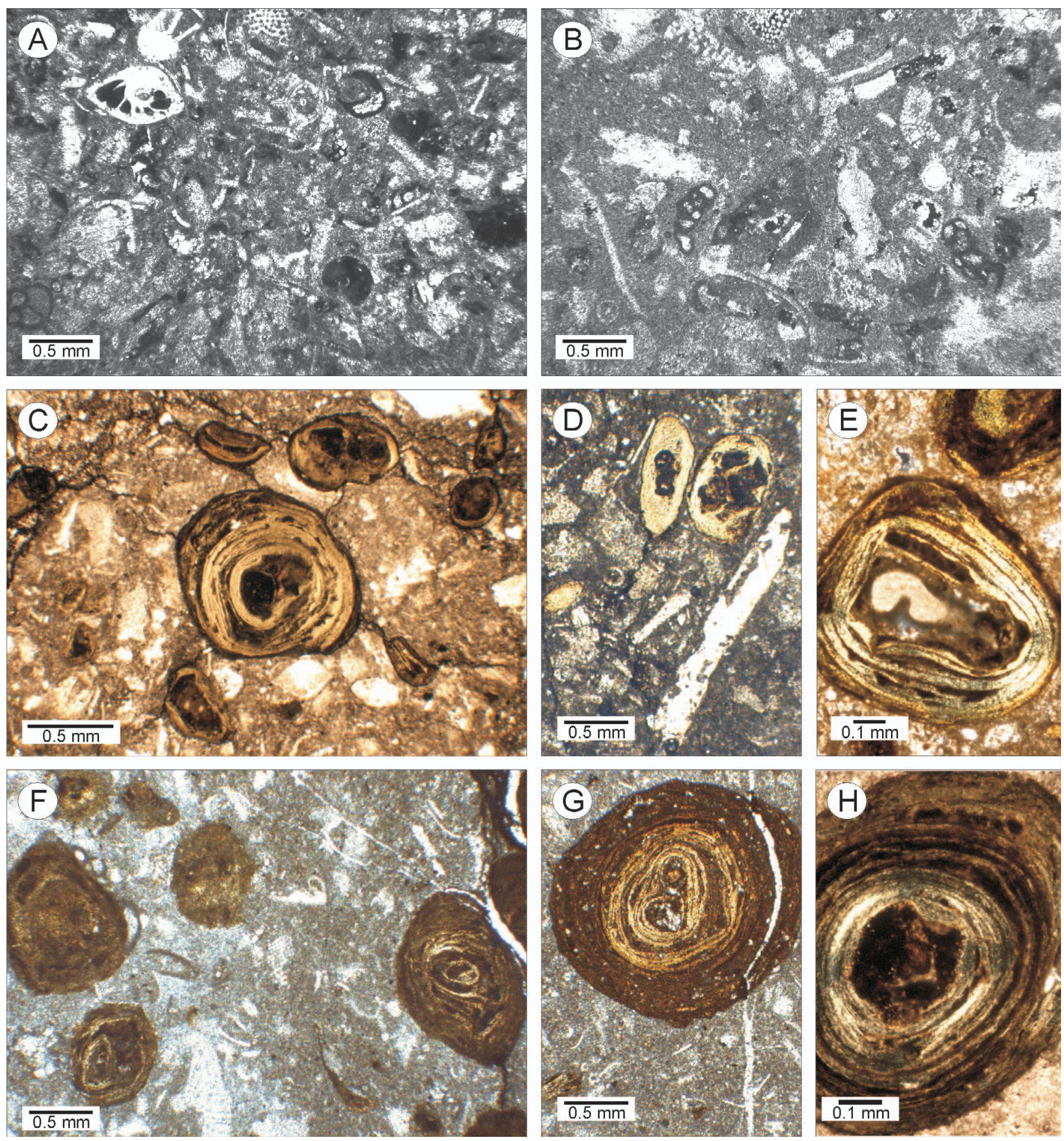

FIG. 5.-Iron-coated particles, stages 1-3 (petrographic thin sections): A) Stage 1, totally or partially iron-replaced fossils, some affected by iron precipitation inside their tests, embedded in an iron-rich peloidal matrix (plane-polarized light). B) Stage 1, ferruginized foraminifera tests and echinoderms plates (plane-polarized light). CE) Stage 2, iron ooids: development of a small number of regular coatings of berthierine around a nucleus, C) subrounded iron ooids with encrusters interbedded within the coatings (plane-polarized light), D) ellipsoidal iron ooids (plane-polarized light), E) subrounded iron ooid, with interbedded encrusters within sets of laminae (crosspolarized light), F-H) Stage 3, iron oncoids: development of irregular goethite coatings of variable thickness, frequently associated with encrusters, around previous particles, F) ellipsoidal iron oncoids; note encrusters on the left particle (plane-polarized light), G) rounded iron-coated particle showing the development of oncoid layers that incorporate quartz grains over previous ooid-like ones (plane-polarized light), $\mathbf{H}$ ) rounded iron-coated particle, with berthierine in the inner coatings (see interference cross) and goethite in the outer ones (cross-polarized light). 

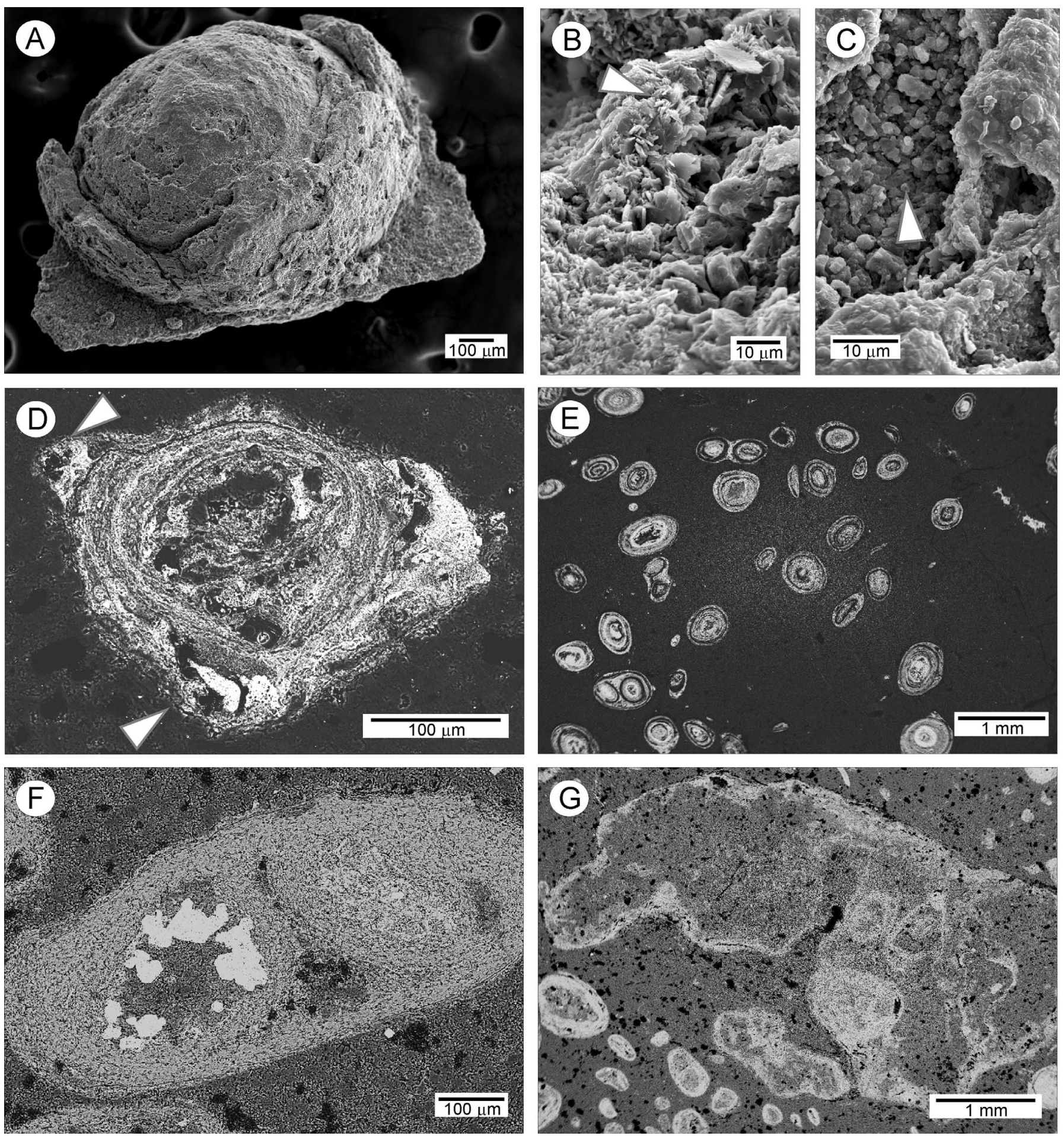

FIG. 6.--Iron-coated particles under SEM, A-C) secondary electron images, and D-G) back-scattered electron images, where the darker areas correspond with calcite (matrix and unaltered fossils), the light-gray ones with berthierine, and the white ones with iron oxides. A) Arrangement of coatings around a nucleus in a broken irononcoid. B) Detail of berthierine crystallites in one coating (arrow). C) Detail of goethite crystals in one coating (arrow). D) Irregular arrangement of coatings of an iron oncoid (polished thin section). Note the encrusters on the outer coatings (arrows). E) General view of iron-coated particles in a polished thin section, note that some of them are polynucleous. F) Detail of a polynucleous particle (polished thin section). The left nucleus has been replaced by pyrite (very light gray). G) Iron intraclasts (lower left) and partially ferruginized aggregate grain (grapestone) in polished thin section. 

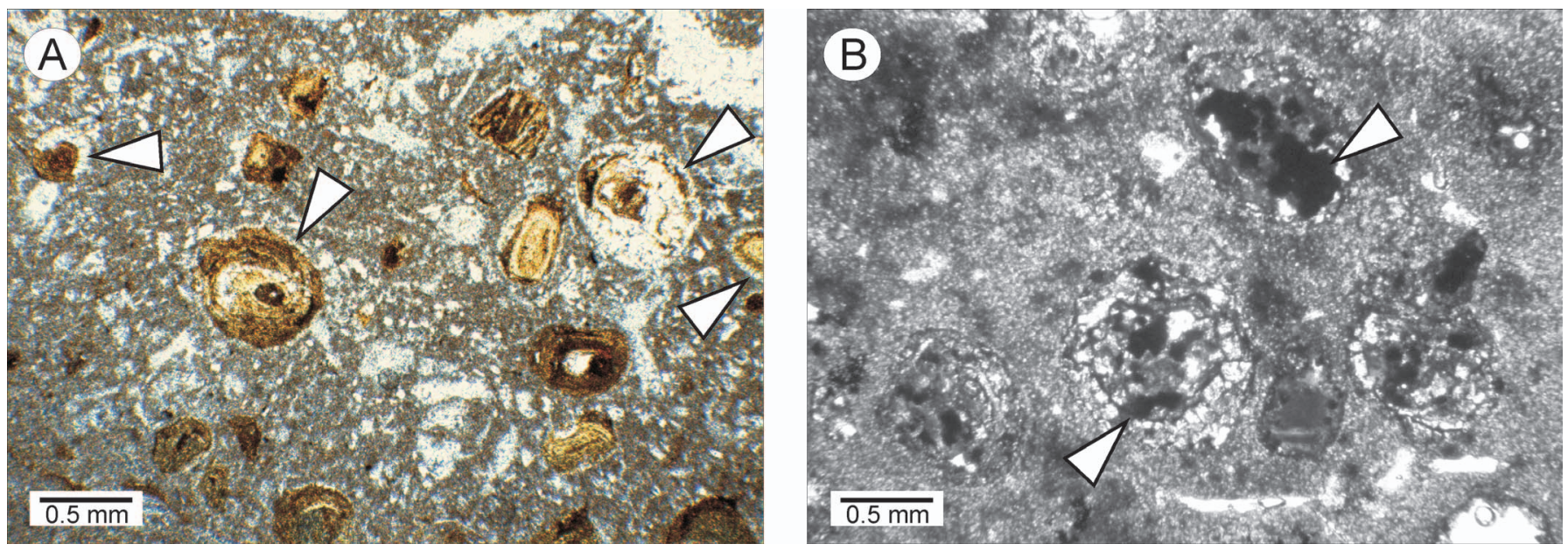

FIG. 7.- Iron-coated particles, diagenetic stages (petrographic thin sections, plane-polarized light). A) Development of anisopachous circumgranular cement around iron-coated particles (arrows), B) ghost particles, with internal undissolved residual iron (arrows).

\section{Geochemical Character of Trace Elements}

Rare Earth Elements and Yttrium.-Because rare earth elements and yttrium (REY) are not easily fractionated during sedimentation, sedimentary REY patterns may provide an index to average provenance compositions (McLennan 1989). For example, similarities in distribution patterns of rare earth elements and immobile elements between iron ooids and volcanic rocks can be important for evaluating volcanic influence on the genesis of those ooids (Sturesson 2003; Sturesson et al. 2000).

The abundance of REY in bulk samples containing iron-coated particles, limestones, and marls varies in the samples of the Iberian Range (Table 2). The REY distribution patterns for the iron-coated particles within the carbonate strata and for coeval volcanic rocks (late Toarcian-early Bajocian) in the Iberian Range (Martínez González et al. 1997) are compared on Chondrite-normalized (Fig. 8) and PAASnormalized curves (Fig. 9) together with the character of present-day iron ooids and seawater, and ancient iron ooids and iron crusts.

On Chondrite-normalized spidergrams, the LREE patterns of ironcoated particles, volcanic rocks, present-day iron ooids from Indonesia (Fig. 8A, B), and contemporaneous carbonates without iron particles (Fig. 8C) have a similar trend. They all lack a clear Ce depletion, but they differ in LREE concentration, ranging from higher values for volcanics, intermediate for Indonesian iron ooids and carbonates with iron-coated particles, and slightly lower values from Fuentelsaz carbonates (e.g., marls show the higher concentrations). However, they clearly differ from the trend of the Oxfordian ooids type A of the Prebetic (Betic Cordillera) (Fig. 8B), present-day Pacific seawater (Fig. 8D), both of which exhibit a marked Ce depletion, and the PAAS (Fig. 8A). MREE patterns from all the samples are more regular, including only a slight stepwise decrease (even flat shapes in the Oxfordian samples), with a marked Eu depletion, except for the volcanics. In contrast, only Pacific seawater includes increased MREE values. Finally, the LREE values are quite similar (rather flat shape) for the PAAS, the Oxfordian iron ooids, and most of the sedimentary Aalenian-Bajocian samples, whereas the rest of the samples exhibit different trends.

The PAAS-normalized patterns (Fig. 9) enhance distinctions between the Betic Cordillera Oxfordian iron ooids and those from the Iberian Range and from Indonesia. The Ce depletion of the Oxfordian ooids (Fig. 9A) is the most pronounced of all samples, with higher REY concentrations than the other iron-coated samples and present-day iron ooids, but also than those of the carbonates of Fuentelsaz (Fig. 9B).

\section{DISCUSSION}

\section{Interpretation of Iron-Coated Particles}

Petrographic and geochemical data indicate several stages in the evolution of iron particles in this succession. Stage 1 represents the beginning of formation of an iron particle (Fig. 10). During early burial, echinoderm plates typically are affected by micro-dissolution that enlarges the pores in stereom, where precipitation of iron minerals was favored. In bryozoans and foraminifera, iron minerals began to precipitate in empty chambers. The appearance of pyrite inside foraminiferal tests suggests the development of sulfidic microenvironments. Replacement of bioclasts by ferruginization processes involves loss of primary structure, although, in some cases, shells or tests remain unaltered or carbonate (calcitic) cements precipitated. This first stage appears throughout the succession, although iron-rich particles are more abundant in condensed beds of the younger strata.

Stage 2 involves the development of regular, concentric laminae around pre-existing, ferruginous particles (Fig. 10). In accord with their mineralogy, these iron ooids have undergone periods with predominating reduced conditions (berthierine), alternating with oxidizing phases (goethite). These grains may have remained buried most of the time, but embedded in soft sediment in a suboxic environment, may have been remobilized, modified by changes in the redox boundary inside the sediment, and modified by bioturbation. Although they appear in intervals characterized by low sedimentation rates, it is plausible that the development of the (relatively few) berthierine laminae was intimately related to redox fluctuations within the sediment.

Stage 3 corresponds to the final stage of the depositional genesis of iron-rich grains, caused by the colonization by encrusters of particles under oxic conditions (Fig. 10). Older particles were exhumed, and exposed enough for encrusters (Nubecularia, serpulids, and bryozoans) to cover the particles and generate more complex, partially ferruginized aggregate grains and iron oncoids. The fixation and overgrowth of encrusters on previous particles indicate that their surfaces were lithified. The encrustations are interpreted to have occurred in association with very low sedimentation rates, which favored intense reworking and bioturbation that homogenized the sediment.

Finally, with burial, diagenetic modifications affected some of the ironcoated particles and other grains. These alterations include precipitation of carbonate cement, partial recrystallization (calcitization), and dissolution (Fig. 10). These modifications resulted in berthierine and calcitic rims (Diagenetic phase A) or formation of ghost particles with 


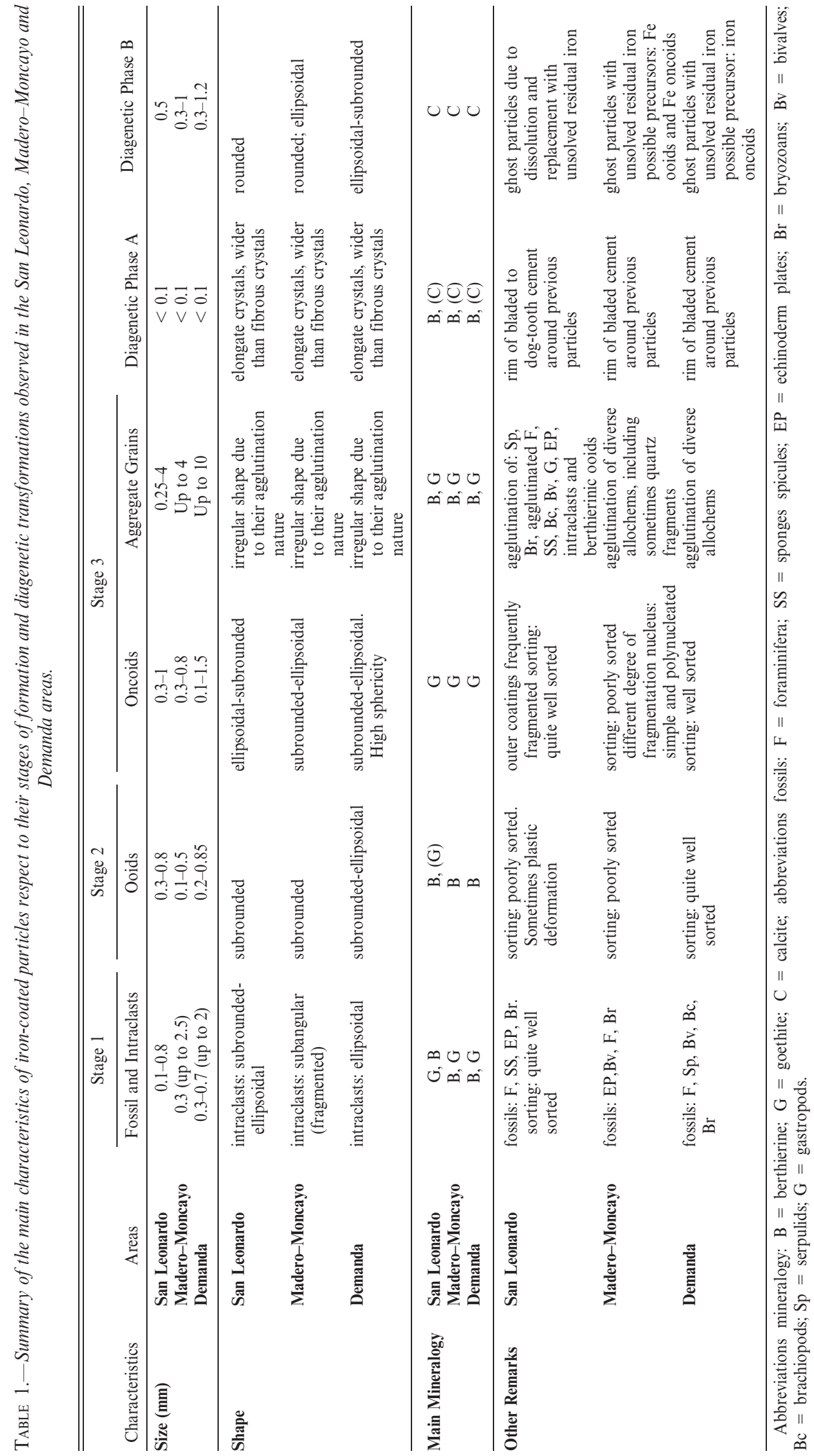




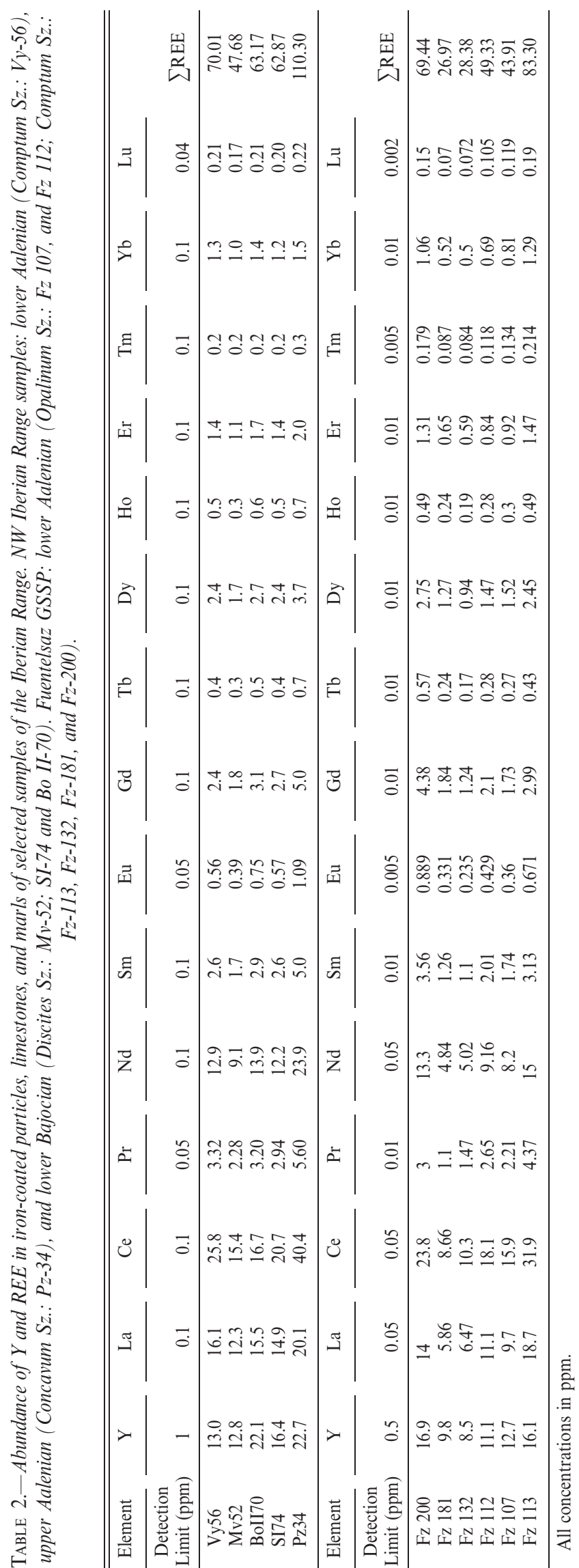

undissolved residual iron due to dissolution and calcite replacement (Diagenetic phase B). In the latter case, the partial or total replacement by neoformed calcite destroys the original texture of the iron-rich particles forming ghost particles. Other, less common replacement minerals include iron sulfides (pyrite).

\section{Geochemical Inferences}

Redox State.-Rare earth elements exist mostly in a trivalent state, but there are two exceptions to this generality, europium and cerium (which may also exist as $\mathrm{Eu}^{2+}$ and $\mathrm{Ce}^{4+}$ respectively). The Eu depletion in the Chondrite-normalized samples (Fig. 8) is consistent with other sedimentary patterns (e.g., Zhang et al. 1998; McLennan 1989). However, Ce is one of the most variable rare earth elements both in Chondrite-normalized and PAAS-normalized spidergrams. Cerium becomes oxidized on a large scale in the oceans to $\mathrm{Ce}^{4+}$, a state that is exceedingly insoluble and is rapidly incorporated in bottom sediments, particularly Mn nodules (McLennan 1989). As a result, Chondrite-normalized plots from phases precipitated in equilibrium with seawater commonly show distinct Ce depletion as the immediate consequence of this reaction (Fryer 1983; McLennan 1989). For example, the Pacific seawater patterns (Fig. 8D) from Zhang and Nozaki (1996) reflect the very low concentrations of REE in marine waters, and represent the oxygenation levels at $0,-2$, and -46 meters, with increasing Ce depletion at greater depth.

Studies of REE concentrations of dissolved and suspended particulates in the Cariaco Trench (Venezuela; from de Baar et al. 1988) show that the Ce gradient in the oxic-anoxic interface is more pronounced than that evident for other REE. When normalized to shale, a marked Ce depletion is evident in the distribution patterns of dissolved rare earth elements under oxic conditions, whereas no depletion or even a $\mathrm{Ce}$ enrichment occurs in anoxic settings.

The variations depicted in Jurassic Chondrite- and PAAS-normalized samples of the Iberian Range (from a minor to a distinct Ce depletion, see Fig. 9B) might be explained by changes in the oxidation-reduction reactions related to periods or places with changing geochemical conditions. If so, they should also be reflected in the mineralogy of the particles.

Mineralogy.-The mineralogy of the iron-coated particles shows changes in composition revealing oscillations in the redox conditions. Co-occurrence of suboxic and oxic phases is common in most hydrothermal deposits, indicating a range in redox conditions over either short spatial scales or through time (Severmann et al. 2004). The coexistence of both phases within the iron-coated particles from the study area is consistent with the conceptual model of Jeans et al. (2000), wherein the development of suboxic and anoxic conditions occurs only below the water-sediment interface. In fully marine conditions, berthierine is considered to be precipitated within the suboxic diagenetic zone (Taylor 1998). Thus, precipitation should be linked with suboxic conditions in earliest stages of diagenesis, most likely below the active sediment-water interface. Subsequent periods of low sediment accumulation allowed the exhumation of particles, reworking, and exposure to oxic conditions. Goethite is interpreted to represent these periods, which also favored the growth of encrusters on the surface of the iron-coated particles. Berthierine can also be produced in nominally oxygenated conditions during sediment ingestion and excretion, since guts of animals are micro-reducing environments even within an oxic zone of sediments (Needham et al. 2004, 2005). On the other hand, these biological casts show contorted structures that are not present in the Aalenian samples.

\section{Synthesis-Evolution of Iron-Coated Particles}

Regional Setting and Types of Iron Particles.-A stable epeiric platform characterized the NW part of the Iberian Basin until the early Aalenian, 
A
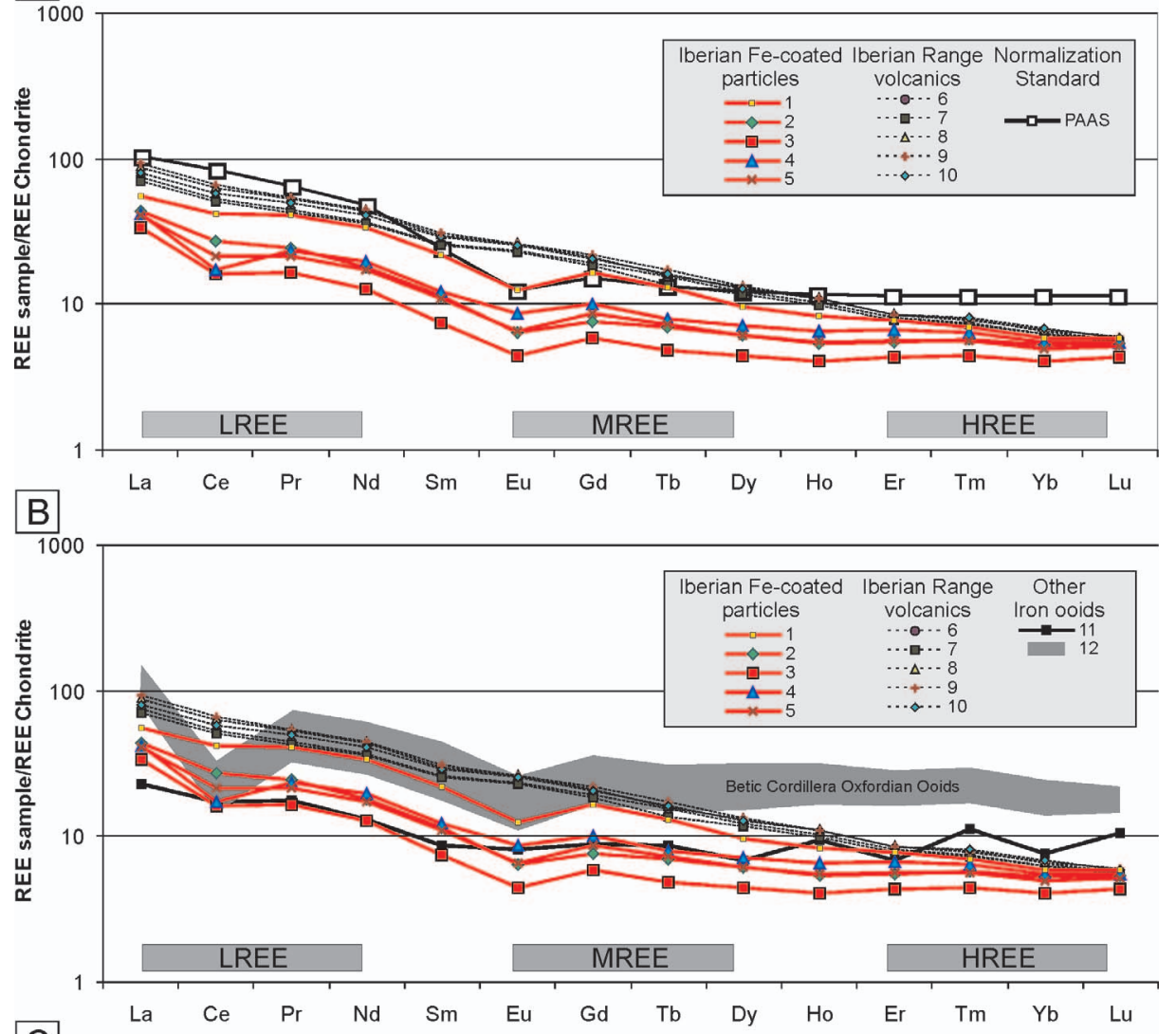

C

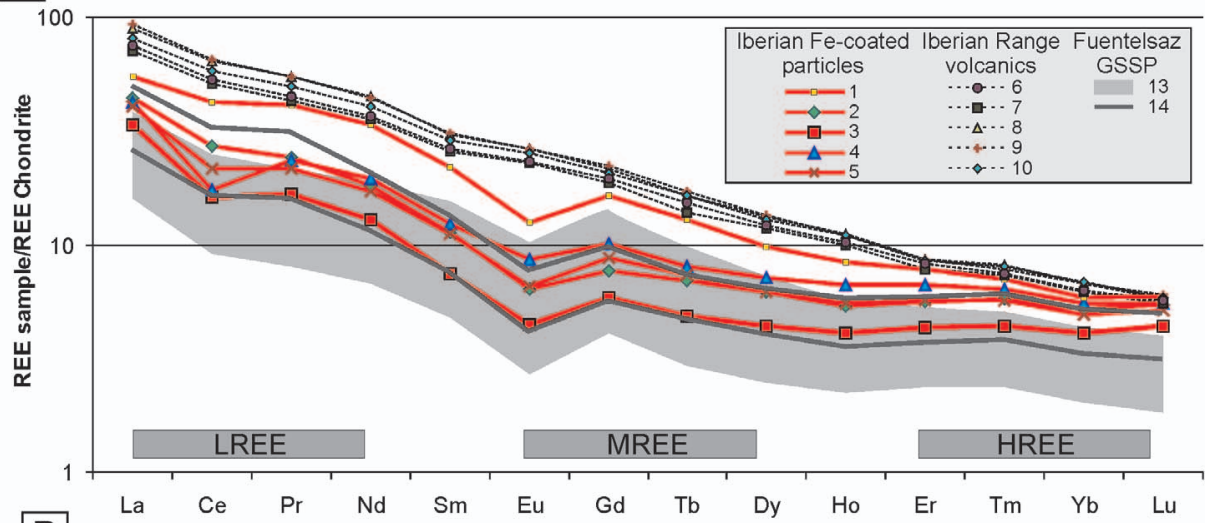

D

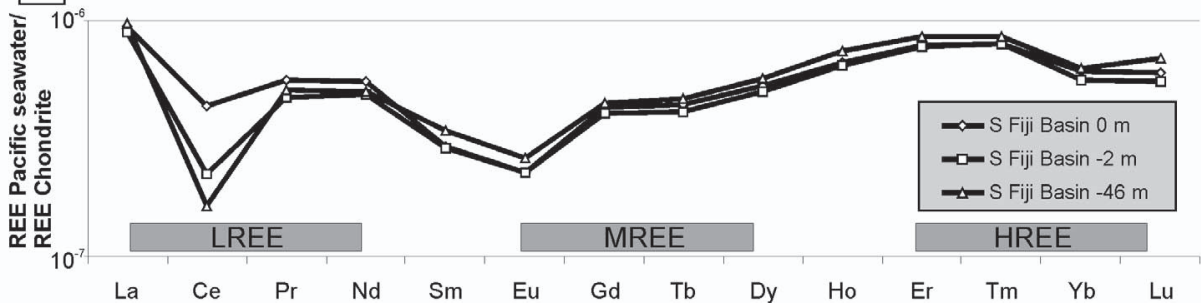

FIG. 8.-Chondrite-normalized (Taylor and McLennan 1985) REE distribution patterns for five selected carbonate samples (1-5) in the NW Iberian Range containing iron-coated particles $(1$ = Pz-34, Comptum Sz.; 2 = Vy-56, Concavum Sz.; $3=$ Mv-52, $4=$ Bo II-70, and $5=$ Si-74, Discites Sz.) and five samples of volcanic materials of coeval age (6-10) in SE Iberian Range $(6=$ IR Volc-6; $7=$ IR Volc- 7 ; IR $8=$ Volc-5; $9=$ IR Volc-2, and $10=$ IR Volc-9 from Martínez González et al. 1997), compared with different samples. A) Values of a standard shale: PAAS (Taylor and McLennan 1985); B) modern Indonesian iron ooids (11) related with a volcanic setting and with Oxfordian plinthitic iron ooids (12) of the Betic Cordillera (Reolid et al. 2008); C) values of limestones (13) and marls (14) of the Fuentelsaz GSSP for the Toarcian-Aalenian boundary, and D) Pacific seawater, South Fiji Basin (Zhang and Nozaki 1996) which extended to southern areas, like Fuentelsaz. After late Comptum Biochron (early Aalenian), a differentiation in two major facies domains occurred in the NW Iberian Basin (IB domain vs. BCB domain), most likely caused by active extensional faulting (García-Frank et al. 2008) and in certain places iron-coated particles developed (Stage 1, and subordi- nately, Stage 2). During the Murchisonae and Bradfordensis Biochrons (middle Aalenian), condensed sequences with abundant iron-coated particles (Stages 1 and 2) formed on top of elevated fault blocks (halfgraben structures with associated paleo-highs) in the IB domain. Locally, suboxic conditions developed below the active water-sediment interface, 


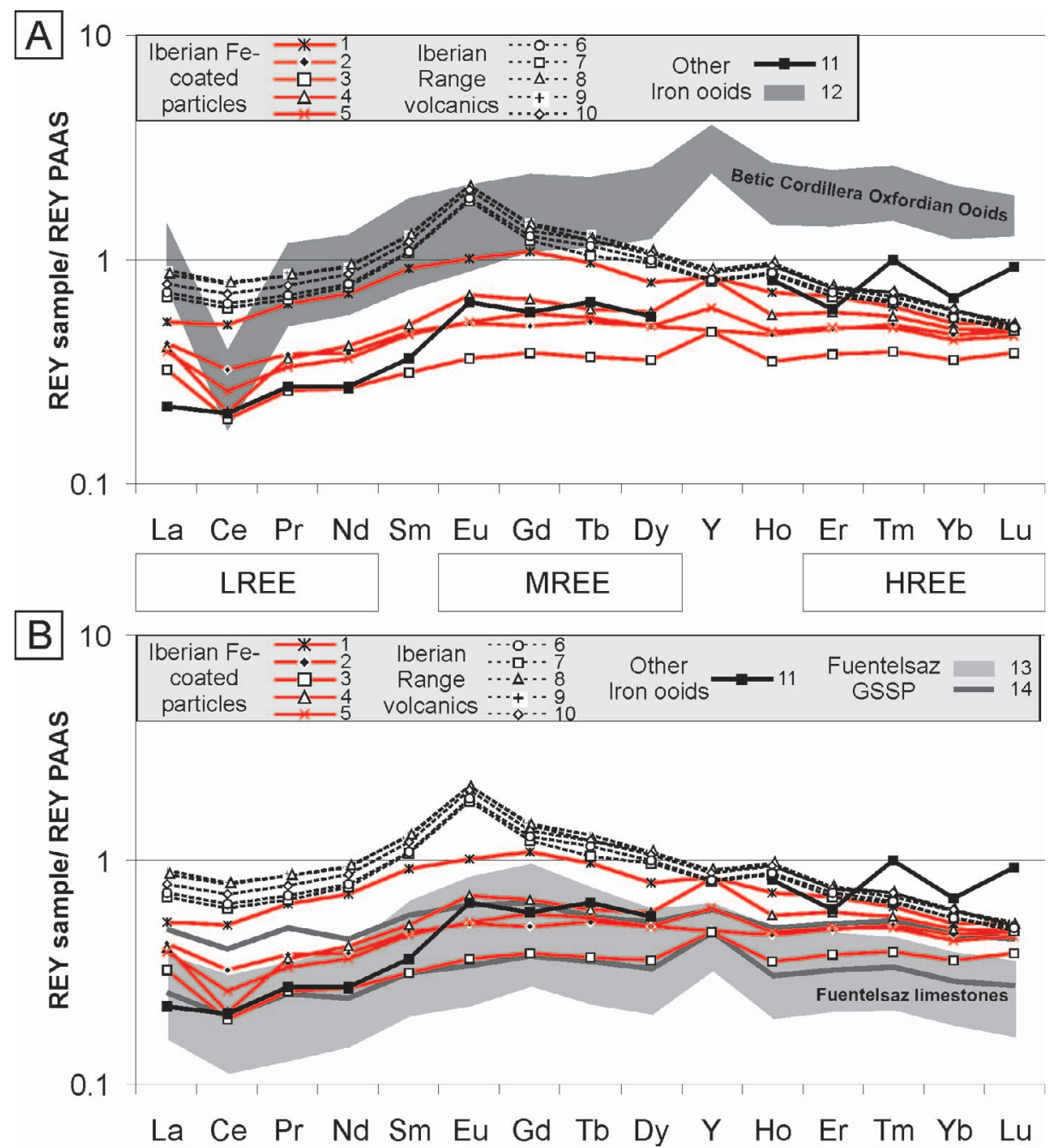

FIG. 9.-PAAS-normalized (Taylor and McLennan 1985) REY distribution patterns for the samples in Figure 8. resulting in berthierine precipitation. During the Concavum Biochron (late Aalenian), throughout the IB domain, the sedimentation rate dropped in most areas and favored widespread occurrence of all different types of ironcoated particles (Stages 1, 2, and 3). Successive reworking processes allowed the exhumation of particles and their exposure to oxic conditions where encrusters grew and goethite precipitated. Finally, in the course of the Discites Biochron (early Bajocian) the maximum condensation occurred, and all the stages were frequently affected by early diagenetic modifications. The suite of different iron-coated particles formed (or transformed) by the aforementioned processes, point that the decreasing sediment accumulation rate was the main factor affecting the system. The Fe-coated particles chemistry itself can enhance the low sediment rate, since if the time exposure to seawater is long enough, they can record its REY composition. Some PAAS-normalized REY ratios ( ${ }_{\mathrm{PN}}$ ) can provide specific information related to time exposure to seawater. The $(\mathrm{Dy} / \mathrm{Yb})_{\mathrm{PN}}$ values for modern seawater and other carbonates through the Phanerozoic range from 0.8 to 1.1 (Shields and Webb 2004). Some of the (Dy/Yb) the carbonates with Fe-coated particles (Table 3) fall between this interval. Since they had enough time exposure to seawater as result of the lower rates of sedimentation, this can be detected trough their ratios and thus represent a new record of total $\mathrm{Dy} / \mathrm{Yb}$ concentration values for Aalenian-early Bajocian seawater.

Source of Iron.-Iron in Jurassic ironstones frequently is suggested to be a product of deeply weathered plinthitic soils (e.g., Reolid et al. 2008).
However, no such paleosols are known in the Aalenian sediments of adjacent areas in the Iberian Range. Instead, these iron-coated particles developed in a geological setting of semiarid climate (Rees et al. 2000; Barrón et al. 2010), with the nearest terrigenous source being emerged areas hundreds of kilometers away (see García-Frank et al. 2008). The palynological assemblages at the GSSP of Fuentelsaz correspond to subtropical plant communities (gymnosperms and vascular cryptogams), adapted to arid conditions (Barrón et al. 2010). In this setting, the main source of metals likely were hydrothermal solutions related to volcanism, mixed with seawater in variable proportions, and precipitated as colloids. Thus, a more likely source for the $\mathrm{Al}, \mathrm{Si}$, and $\mathrm{Fe}$ of the silicates is the coeval volcanism (lower Toarcian-lower Bajocian) in the southeastern Iberian Range, or other, regionally widespread Jurassic magmatic activity (see Geological Setting). On Chondrite- and PAAS-normalized spidergrams, the differences between the Iberian iron-coated particles and goethitic Oxfordian ooids are interpreted to reflect a different source of the elements in each case. Since the Oxfordian ooids (type A) are related to weathering processes (Reolid et al. 2008), the REY pattern exhibits a different shape. The present-day Indonesian ooids are related to a volcanic source of iron, and their pattern is similar to those of the Iberian iron-coated samples and the Aalenian carbonates of Fuentelsaz, which have slightly lower concentrations.

To test provenance, LREE, MREE, and HREE values of the samples were compared with different materials (igneous and sedimentary) of diverse geological contexts on ternary plots (Fig. 11). The sedimentary 


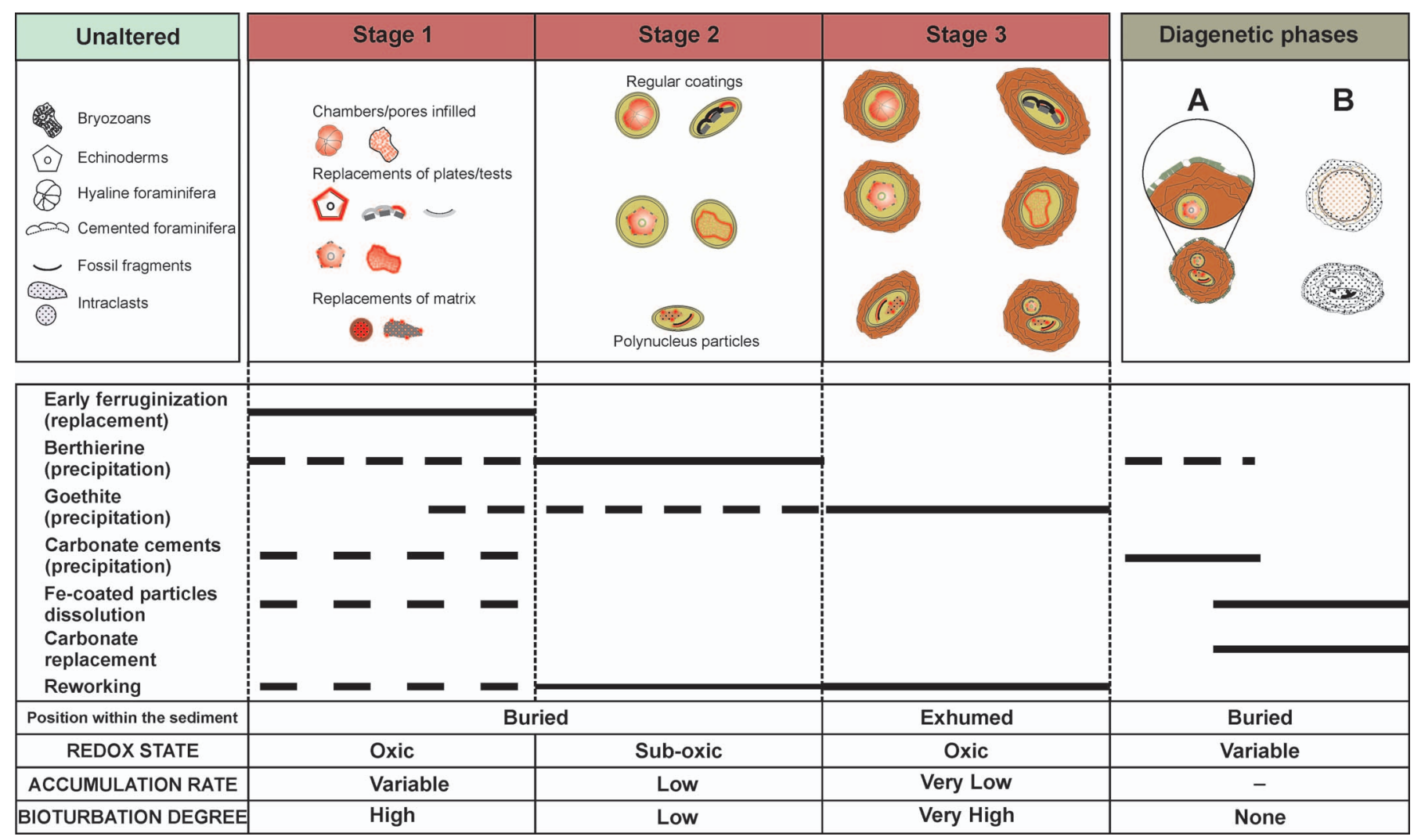

FIG. 10.-The three stages of iron-particle formation and diagenetic phases, suggested by differences in iron-coated particles. The geochemical environment, sedimentary rates, and bioturbation are distinct within each stage of particle formation.

materials from this area, and the coeval volcanics of the Iberian Range, fall within a very well-defined field (Fig. 11, upper right corner), whereas all the samples linked with a "nonmarine" genesis (laterites and pisoids) plot in a different field, with lower MREE values. The two comparison standards (PAAS and chondrite) are projected independently, whereas the remaining samples are clustered nearby the Iberian Range samples. Like these Iberian iron-coated and coeval volcanic samples, data from Ordovician iron ooids and volcanic rocks (Sturesson 2003) show some

TABLE 3.-Dy/Yb PAAS-normalized ratios in Aalenian-Bajocian selected samples from the Iberian Basin.

\begin{tabular}{llc}
\hline \hline & & $(\mathrm{Dy} / \mathrm{Yb})_{\mathrm{PN}}$ \\
\hline Iberian Range Volcanics $^{1}$ & IR Volc 6 & 1.8 \\
& IR Volc 7 & 1.76 \\
& IR Volc 5 & 1.84 \\
& IR Volc 2 & 1.8 \\
& IR Volc 9 & 1.75 \\
Iron-Coated Particles & Vy56 & 1.09 \\
& Mv52 & 1 \\
& BoII70 & 1.19 \\
& SI74 & 1.16 \\
Limestones & Pz34 & 1.53 \\
& Fz 200 & 1.56 \\
& Fz 181 & 1.47 \\
Marls & Fz 132 & 1.13 \\
& Fz 112 & 1.28 \\
& Fz 107 & 1.13 \\
& Fz 113 & 1.14 \\
\hline
\end{tabular}

\footnotetext{
${ }^{1}$ Data from Martínez-González et al. 1997.
}

dispersion. The other iron ooids (Oxfordian type A, from Reolid et al. 2008; and present-day samples, from Sturesson et al. 2000) plot adjacent to the Ordovician samples. Since our samples are from bulk rock, i.e., they represent mixed samples, they fall within the values of coeval sedimentary and volcanic rocks, as happens with mixed UK Jurassic deposits (Jeans et al. 2000).

The plot of yttrium versus niobium and lanthanum permitted distinction between concentrations typical of magmatic sources and those resulting from weathering (solid arrows in Fig. 12; Class and le Roex 2008). The plot shows no indication for mobilization of Y or La, as would be indicative of a weathering source (Class and le Roex 2008). Thus, a magmatic trend is more consistent with the data than a weathering cause. In this context, the different signatures of REY patterns and LREE, MREE, and HREE values are controlled by tectonic instability in the study area consistent with a mixture of coeval sedimentary and volcanic-derived sources.

In summary, carbonates containing Fe-coated particles can provide information about the provenance source chemistry, including aspects such as volcanism or seawater input, and may be useful to understand other successions where these particles appear. The REY patterns and their evolution through the sedimentary record highlight the roles played in the REY budget by Fe-coated particles and marine carbonates, as other studies have predicted (e.g., Négrel et al. 2006). Nonetheless, the exposure time to seawater can exert a strong control on the REY chemistry of the sediment. These carbonates with Fe-coated particles can be attributed to a low sedimentation rate, which enhanced REY absorption (and fractionation) from seawater. Thus, carbonates with Fe-coated particles in condensed series can be a good proxy for marine seawater. 
FIG. 11.-Ternary plots of the LREE, MREE, and HREE of several samples of different materials and geological contexts can test provenance. Sedimentary materials and coeval volcanics of the Iberian Range fall within a very well-defined field whereas laterites and pisoids ("nonmarine" genesis), and comparison standards plot in different fields. $1=\mathrm{NE}$ Iberian Range volcaniclastic rocks (Martínez González et al. 1997); 2 = mixed Jurassic deposits, UK (Jeans et al. 2000); 3 = Indonesian iron ooids (Sturesson et al. 2000); $4=$ Ejpovice iron ooids and volcanic rocks (Sturesson 2003); 5 = Oxfordian Betic plinthitic iron ooids type A (Reolid et al. 2008); 6 = Sta Augusta laterites (Morey and Setterholm 1997);

7 = Brazilian pisoids (Tazaki et al. 2009);

8 = Chondrite (Taylor and McLennan 1985);

9 = PAAS (Taylor and McLennan 1985).

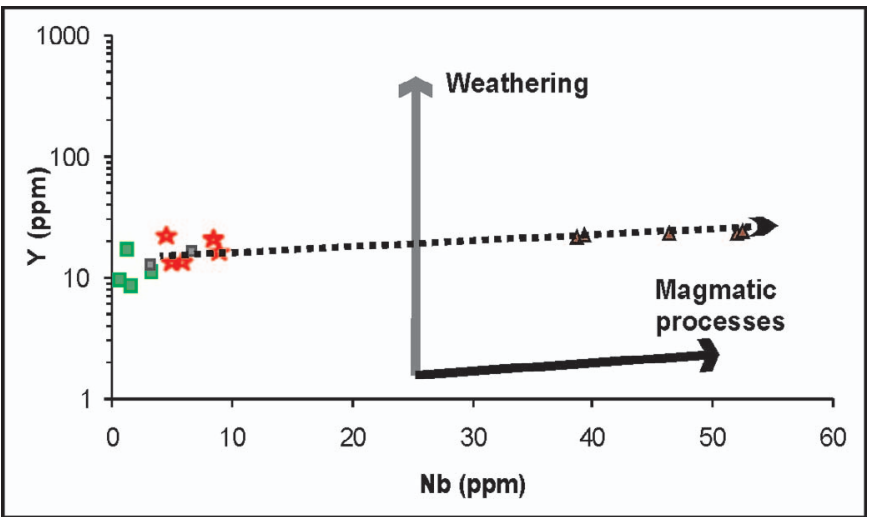

口 Fuentelsaz marls $\star$ NW Iberian Range iron coated particles

- Fuentelsaz limestones $\Delta$ SE Iberian Range volcanics

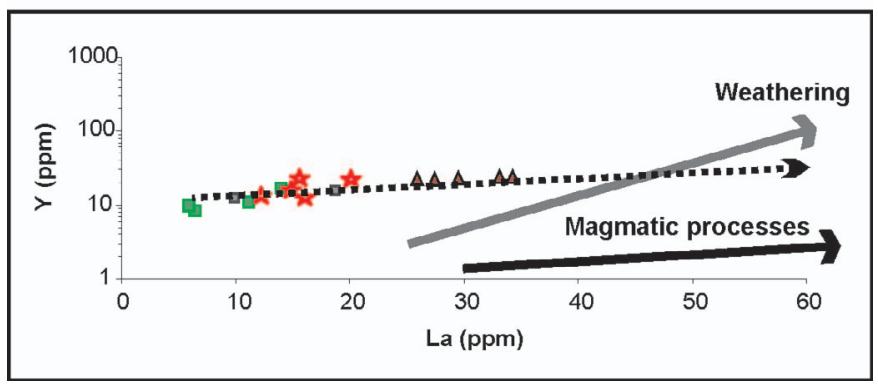

FIG. 12.-Possible trends of provenance of iron-coated particles. Solid arrows indicate concentrations typical of magmatic processes and weathering, and are based on analyses from basalts weathered in tropical and temperate climates (Class and le Roex 2008). The iron-coated particles from this study show trace-element systematics consistent with a mixture of coeval sedimentary and magmatic processes (dotted arrows).

\section{CONCLUSIONS}

1. Three stages of development of iron-coated particles occur in sediments from the condensed Aalenian-Bajocian interval of the NW Iberian Range, Spain. Stage 1 corresponds to ferruginized carbonate grains (Fe-skeletal grains, Fe-peloids, and Fe-cortoids); Stage 2 is represented by berthierinic iron ooids, and Stage 3 comprises goethitic irregular coatings (oncoids and grapestones) developed around the previously developed particles. Beyond depositional processes, early diagenetic modifications, such as formation of cements around iron-coated particles (diagenetic phase A) or dissolution and calcite replacement (diagenetic phase B), also influenced these sediments.

2. Geochemical data (cerium variations of the REY patterns) suggest changes in the oxidation-reduction conditions during deposition. A mixture of reduced and oxidized iron mineral phases in individual Fe-coated particles also suggests highly variable redox conditions. Berthierine is interpreted to be linked with suboxic conditions, whereas goethite and the appearance of encrusters suggest oxic conditions.

3. Basin evolution and tectonics played a role in the genetic model of these particles by providing means for surface-water enrichment of $\mathrm{Fe}$, and creating different domains in which the Fe-coated particles developed. The different stages of iron-coated particles developed in specific stratigraphic levels with different sedimentation rates. The decreasing sediment accumulation rate was the main factor affecting the genesis of the different types of Fe particles.

4. The source of iron has been inferred due to the comparison of REY spidergrams, ternary plots of LREE, MREE, and HREE, and the $\mathrm{Y} / \mathrm{Nb}$ and $\mathrm{Y} / \mathrm{La}$ plots from different geological contexts, which display specific signatures. Given the lack of evidence for nearby lateritic or plinthitic soils during this period, coeval Iberian volcanism is the most plausible source of iron. The projection of LREE, MREE, and HREE values of iron-rich samples on ternary plots matches that of contemporaneous Aalenian GSSP sedimentary rocks and the volcanics. Likewise, they show no indication for mobilization of either $\mathrm{Y}$ or $\mathrm{La}$, as would be expected for a source related to weathering; instead, they show trace-element systematics 
consistent with a mixture of coeval sedimentary and magmatic processes.

5. REY PAAS-normalized patterns are an adequate tool for provenance analyses. The (Dy/Yb) PAAS-normalized ratios help to discriminate seawater concentrations. Carbonates with Fe-coated particles with $(\mathrm{Dy} / \mathrm{Yb})_{\mathrm{PN}}$ values between 0.8 and 1.1 in known regimes of low sedimentation rates may document REY absorption and fractionation from seawater. Thus, carbonates with Fe-coated particles in condensed series can be good paleoceanographic proxies.

\section{ACKNOWLEDGMENTS}

We want to thank Dr. M.M. Kimberley and the North Carolina State University for the valuable help during the research fellowship of A. GarcíaFrank. We thank the comments provided by Reviewers Prof. David Budd, Prof. Kevin G. Taylor, Prof. Tadeusz Peryt, and Prof. Matias Reolid, Associate Editor Prof. Richard H. Worden, and Editors Kitty Milliken and Prof. Eugene C. Rankey that greatly improved earlier versions of this manuscript. Special thanks for the careful text revisions provided by Prof. D. Budd and Prof. E.C. Rankey. This work was funded by the projects CGL2005-04574 and CGL2011-25894 of the Secretaría de Estado de Universidades e Investigación and the project 910431 (UCM-CAM).

\section{REFERENCES}

Arias, C., García-Frank, A., Canales, M.L., and Ureta, S., 2009, Ostracods from the Global Stratotype Section for the base of the Aalenian stage, Jurassic at Fuentelsaz section (Cordillera Ibérica, Spain): Rivista Italiana di Paleontologia e Stratigrafia, v. 115 , p. 209-232.

Aurell, M., Robles, S., Bádenas, B., Rosales, I., Quesada, S., Meléndez, G., and Garcia-Ramos, J.C., 2003, Transgressive-regressive cycles and Jurassic palaeogeography of northeast Iberia: Sedimentary Geology, v. 162, p. 239-271.

Azañón, J.M., Galindo-Zaldívar, J., García-Dueñas, V., and Jabaloy, A., 2002, Alpine tectonics II: Betic Cordillera and Balearic Islands, in Gibbons, W., and Moreno, M.T., eds., The Geology of Spain: Geological Society of London, p. 401-416.

Barrón, E., Ureta, S., Goy, A., and Lassaletta, L., 2010, Palynology of the ToarcianAalenian Global Boundary Stratotype Section and Point (GSSP) at Fuentelsaz (Lower-Middle Jurassic, Iberian Range, Spain): Review of Palaeobotany and Palynology, v. 162, p. 11-28.

BERNER, R.A., 1981, New geochemical classification of sedimentary environments: Journal of Sedimentary Petrology, v. 51, p. 359-365.

Class, C., And le Roex, A.P., 2008, Ce anomalies in Gough Island lavas - trace element characteristics of a recycled sediment component: Earth and Planetary Science Letters, v. 265, p. 475-486.

Cresta, S., Goy, A., Ureta, S., Arias, C., Barrón, E., Bernard, J., Canales, M.L., García Joral, F., García Romero, E., Gialanella, P.R., Gómez, J.J., González, J.A., Herrero, C., Martínez, G., Osete, M.L., Perilli, N., and Villalaín, J.J., 2001, The Global Boundary Stratotype Section and Point (GSSP) of the Toarcian-Aalenian Boundary (Lower-Middle Jurassic): Episodes, v. 24, p. 166-175.

de Baar, H.J.W., German, C.R., Elderfield, H., and Van Gaans, P., 1988, Rare earth element distributions in anoxic waters of the Cariaco Trench: Geochimica et Cosmochimica Acta, v. 52, p. 1203-1219.

DreEsen, R., 1989, Oolitic ironstones as event-stratigraphical marker beds within the Upper Devonian of the Ardeno-Rhenish Massif, in Young, T.P., and Taylor, W.E.G., eds., Phanerozoic Ironstones: Geological Society of London, Special Publication 46, p. 65-78.

El Hammichi, F., Elmi, S., Faure-Muret, A., and Benshilil, K., 2002, A preaccretional extensional platform of the North African Tethys during the ToarcianAalenian (Iguer Awragh-Afennourir syncline, western Middle Atlas, Morocco): Comptes Rendus Geosciences, v. 334, p. 1003-1010.

Fernández-López, S., Gómez, J.J., And Goy, A., 1985, Le Dogger de Caudiel. Sédimentologie des carbonates développés sur un "monticule" de matériaux volcaniques: Strata, v. 2, p. 101-115.

FlüGEL, E., 2004, Microfacies of Carbonate Rocks: Analysis, Interpretation and Application: Berlin, Springer, $976 \mathrm{p}$.

FRYER, B.J., 1983, Rare earth elements in iron-formation, in Trendall, A.F., and Morris, R.C., eds., Iron-Formation: Facts and Problems: Amsterdam, Elsevier, p. 345-358.

García-Frank, A., 2007, Evolución biosedimentaria y secuencial del Jurásico Medio inferior en la Cuenca Ibérica (Sector NO) [Ph.D. Thesis]: Universidad Complutense de Madrid, Servicio de Publicaciones, available online at http://www.ucm.es/BUCM/ tesis/geo/ucm-t $\% 2029198$.pdf.

García-Frank, A., Ureta, S., And Mas, R., 2006, Tectonically active Aalenian in the Northwestern Iberian Basin (Spain): Volumina Jurassica, v. IV, p. 42.

García-Frank, A., Ureta, S., And Mas, R., 2008, Aalenian pulses of tectonic activity in the Iberian Basin, Spain: Sedimentary Geology, v. 209, p. 15-35.
Gautier, F., And Odin, G.S., 1983, Volcanisme Jurassique du Sud de l'Aragon (Espagne): Société Géologique de France, Comptes Rendus, v. 2, p. 73-77.

Gómez, J.J., AND FernÁNDEZ-LóPEZ, S.R., 2004, Las unidades litoestratigráficas del Jurásico Medio de la Cordillera Ibérica: Geogaceta, v. 35, p. 91-94.

Gómez, J.J., Comas-Rengifo, M.J., And Goy, A., 2003, Las unidades litoestratigráficas del Jurásico Inferior de las cordilleras Ibérica y Costeras Catalanas: Sociedad Geológica de España, Revista, v. 16, p. 227-237.

Goy, A., And Ureta, S., 1990, El Aaleniense en la Cordillera Ibérica: Université Catholique de Lyon, Cahiers, Série Sciences, v. 4, p. 73-87.

Gradstein, F.M., And OGG, J.G., 2004, Geologic time scale 2004-Why, how, and where next!: Lethaia, v. 37, p. 175-181.

GuimerÁ, J., Mas, R., AND Alonso, A., 2004, Intraplate deformation in the NW Iberian Chain: Mesozoic extension and Tertiary contractional inversion: Geological Society of London, Journal, v. 161, p. 291-303.

Haley, B.A., Klinkhammer, G.P., and McManus, J., 2004, Rare earth elements in pore waters of marine sediments: Geochimica et Cosmochimica Acta, v. 68, p. 1265-1279.

Heikoop, J.M., Tsujita, C.J., Risk, M.J., Tomascik, T., and MaH, A.J., 1996, Modern iron ooids from a shallow-marine volcanic setting: Mahengetang, Indonesia: Geology, v. 24 , p. $759-762$.

Henrigues, M.H., Linares, A., Sandoval, J., and Ureta, S., 1996, The Aalenian in the Iberia (Betic, Lusitanian and Iberian Basins): Georesearch Forum, v. 1-2, p. 139-150. Hesselbo, S.P., AND JenKyns, H.C., 1998, British Lower Jurassic sequence stratigraphy, in de Graciansky, P.C., Hardenbol, J., Jacquin, T., and Vail P.R., eds., Mesozoic and Cenozoic Sequence Stratigraphy of European Basins: SEPM, Special Publication 60, p. $561-581$

Jeans, C.V., Wray, D.S., Merriman, R.J., and Fisher, M.J., 2000, Volcanogenic clays in Jurassic and Cretaceous strata of England and the North Sea Basin: Clay Minerals, v. 35 , p. $25-55$.

Kimberley, M.M., 1978, Paleoenvironmental classification of iron formations: Economic Geology, v. 73, p. 215-229.

Kimberley, M.M., 1989, Exhalative origins of iron formations: Ore Geology Reviews, v. 5 , p. $13-145$.

KimberLey, M.M., 1994, Debate about ironstone: has solute supply been surficial weathering, hydrothermal convection, or exhalation of deep fluids?: Terra Nova, v. 6, p. $116-132$

Kimberley, M.M., 2005, Dynamic Earth: Chemistry: New York, Wiley and Sons, 369 p.

Lago, M., Arranz, E., Gil, A., And Pocovi, A., 2004, Magmatismo asociado, in Vera, J.A., ed., Geología de España: Sociedad Geológica de España, Instituto Geológico y Minero de España, p. 522-525.

Lezin, C., Rey, J., Faure, P., Cubaynes, R., Pelissie, T., Durlet, C., and Deconinck, J.-F., 2007, Tectono-biosedimentary recordings at the Lias-Dogger transition: example of the Quercy carbonate platform (Aquitaine Basin, France): Société Geologique de France, Bulletin, v. 178, p. 275-291.

Martín-Algarra, A., Vera, J.A., (Coord.), Crespo-Blanc, A., Díaz de Federico, A., Estévez, A., López-Garrido, A.C., Molina, J.M., Morata, D., Puga, E., and Sanz DE Galdeano, C., 2004, Magmatismo, estructura y evolución tectónica de las Zonas Externas Béticas, in Vera, J.A., ed., Geología de España: Sociedad Geológica de España, Instituto Geológico y Minero de España, Madrid, p. 385-389.

Martinez González, R.M., Lago, M., Valenzuela Ríos, J.I., Vaquer, R., Salas, R., AND Dumitrescu, R., 1997, El volcanismo triásico y jurásico del sector SE de la Cadena Ibérica y su relación con los estadios de rift mesozoicos: Boletín Geológico y Minero, v. 108, p. 367-376.

Mas, R., Benito, M.I., Arribas, J., Serrano, A., Guimerá, J., Alonso, A., And AlonsoAzcÁrate, J., 2003, The Cameros Basin: from Late Jurassic-Early Cretaceous Extension to Tertiary Contractional Inversion-Implications of Hydrocarbon Exploration, Northwest Iberian Chain, North Spain: American Association of Petroleum Geologists, International Conference and Exhibition, Geological Field Trip 11, 56 p.

McLennan, S.M., 1989, Rare earth elements in sedimentary rocks: influence of Provenance and Sedimentary Processes: Reviews in Mineralogy and Geochemistry, v 21, p. 169-200.

Meunier, A., 2005, Clays: Berlin, Springer, 472 p.

Morey, G.B., And Setterholm, D.R., 1997, Rare earth elements in weathering profiles and sediments of Minnesota; implications for provenance studies: Journal of Sedimentary Research, v. 67, p. 105-115.

Needham, S.J., Worden, R.H., And McIlroy, D., 2004, Animal-sediment interactions: the effect of ingestion and excretion by worms on mineralogy: Biogeosciences, v. 1, p. $113-121$.

Needham, S.J., Worden, R.H., And McIlroy, D., 2005, Experimental production of clay rims by macrobiotic sediment ingestion and excretion processes: Journal of Sedimentary Research, v. 75 , p. 1028-1037.

Négrel, P., Casanova, J., And Brulhet, J., 2006, REE and Nd isotope stratigraphy of a Late Jurassic carbonate platform, Eastern Paris Basin, France: Journal of Sedimentary Research, v. 76, p. 605-617.

Pinheiro, L.M., Wilson, R.C.L., Pena dos Reis, R., Whitmarsh, R.B., and Ribeiro, A. 1996, The western Iberia margin: a geophysical and geological overview, in Withmarsh, R.B., Sawyer, D.S., Klaus, D.S., and Masson, D.G., eds., Proceedings of the Ocean Drilling Program, Scientific Results: College Station, Texas, v. 149, p. 3-23.

Rees, P.M., Ziegler, A.M., And Valdés, P.J., 2000, Jurassic phytogeography and climates: new data and model comparisons, in Huber, B.T., Kenneth, G.M., and Wing S.L., eds., Warm Climates in Earth History: Cambridge, U.K., Cambridge University Press, p. 297-318. 
Reolid, M., Abad, I., and Martín-Garcia, J.M., 2008, Palaeoenvironmental implications of ferruginous deposits related to a Middle-Upper Jurassic discontinuity (Prebetic Zone, Betic Cordillera, Southern Spain): Sedimentary Geology, v. 203, p. 1-16.

Rivas-Sanchez, M.L., Alva-Valdivia, L.M., J. Arenas-Alatorre, J., UrrutiaFucugauchi, J., Ruiz-Sandoval, M., and Ramos-Molina, M.A., 2006, Berthierine and chamosite hydrothermal: genetic guides in the Peña Colorada magnetite-bearing ore deposit, Mexico: Earth, Planets and Space, v. 58, p. 1389-1400.

Salas, R., Guimerá, J., Mas, R., Martín-Closas, C., Meléndez, A., and Alonso A, 2001, Evolution of the Mesozoic Central Iberian Rift System and its Cainozoic inversion (Iberian Chain), in Cavazza, W., Roberston, A.H.F.R., and Ziegler, P., eds., Peri-Tethyan Rift/Wrench Basins and Passive Margins: Muséum National d'Histoire Naturelle, Mémoires, v. 186, p. 145-185.

Sandoval, J., Henrigues, M.H., Ureta, S., Goy, A., and Rivas, P., 2001, The Lias Dogger boundary in Iberia: Betic and Iberian Cordilleras and Lusitanian basin: Société Geologique de France, Bulletin, v. 172, p. 385-387.

Severmann, S., Mills, R.A., Palmer, M.R., and Fallick, A.E., 2004, The origin of clay minerals in active and relict hydrothermal deposits: Geochimica et Cosmochimica Acta, v. 68, p. 73-88.

Shields, G.A., And Webb, G.E., 2004, Has the REE composition of seawater changed over geological time?: Chemical Geology, v. 204, p. 103-107.

SPEARS, D.A., 1989, Aspects of iron incorporation into sediments with special reference to the Yorkshire Ironstones, in Young, T.P., and Taylor, W.E.G., eds., Phanerozoic Ironstone: Geological Society of London, Special Publication 46, p. 19-30.

Sturesson, U., 1992, Volcanic ash: the source material for Ordovician chamosite ooids in Sweden: Journal of Sedimentary Petrology, v. 62, p. 1084-1094.

Sturesson, U., 2003, Lower Palaeozoic iron oolites and volcanism from a Baltoscandian perspective: Sedimentary Geology, v. 159, p. 241-256.

Sturesson, U., Heikoop, J.M., and Risk, M.J., 2000, Modern and Palaeozoic iron ooids; a similar volcanic origin: Sedimentary Geology, v. 136, p. 137-146.

TAYLOR, K.G., 1998, Spatial and temporal variations in early diagenetic organic matter oxidation pathways in Lower Jurassic mudstones of eastern England: Chemical Geology, v. 145, p. 47-60.

TaYlor, K.G., and Curtis, C.D., 1995, Stability and facies association of early diagenetic mineral assemblages: an example from ironstone-mudstone succession, U.K.: Journal of Sedimentary Research, v. 65, p. 358-368.

TaYlor, S.R., and McLennan, S.M., 1985, The Continental Crust: its Composition and Evolution; An Examination of the Geochemical Record Preserved in Sedimentary Rocks: Oxford, U.K., Blackwell Scientific Publications, 312 p.
Tazaki, K., Asada, R., Lindenmayer, Z., Shirotori, T., Vargas, J., Nowatzki, C., and CoElHo, O., 2009, Life inhabits rocks: clues to rock erosion from electron microscopy of pisolite at a UNESCO heritage site in Brazil: International Journal of Earth Sciences, v. 98, p. 227-238.

Terrinha, P., Ribeiro, C., Kullberg, J.C., Lopes, C., Rocha, R., Ribeiro, A., 2002, Compressive episodes and faunal isolation during rifting, Southwest Iberia: The Journal of Geology, v. 110, p. 101-113.

Underhill, J.R., AND Partington, M.A., 1993, Jurassic thermal doming and deflation in the North Sea: implications of the sequence stratigraphic evidence, in Parker J.R., ed., Petroleum Geology of Northwest Europe: Geological Society of London, 4th Conference, Proceedings, p. 337-345.

Vail, P.R., Audemard, F., Bowman, S.A., Eisner, P.N., And Perez-Cruz, C., 1991, The stratigraphic signature of tectonics, eustasy and sedimentology-an overview, in Einsele, G., Ricken, W., and Seilacher, A., eds., Cycles and Events in Stratigraphy: Berlin, Springer, p. 617-659.

Velde, B., 1995, Compaction and diagenesis, in Velde, B., ed., Origin and Mineralogy of Clays: Clays and the Environment: Springer-Verlag, p. 220-246.

Wetzel, A., Allenbach, R., And Allia, V., 2003, Reactivated basement structures affecting the sedimentary facies in a tectonically "quiescent" epicontinental basin: an example from NW Switzerland: Sedimentary Geology, v. 157, p. 153-172.

WRIGHT, V.P., AND WILSON, R.C.L., 1984, A carbonate submarine-fan sequence from the Jurassic of Portugal: Journal of Sedimentary Petrology, v. 54, p. 394412

YounG, T.P., 1989, Eustatically controlled ooidal ironstone deposition: facies relationships of the Ordovician open-shelf ironstones of Western Europe, in Young, T.P., and Taylor, W.E.G., eds., Phanerozoic Ironstones: Geological Society of London, Special Publication 46, p. 51-63.

YounG, T.P., AND TAYLoR, W.E.G., 1989, Phanerozoic Ironstones: Geological Society of London, Special Publication 46, $251 \mathrm{p}$

ZHANG, C., WANG, L., ZHANG, S., AND Li, X., 1998, Geochemistry of rare earth elements in the mainstream of the Yangtze River, China: Applied Geochemistry, v. 13, p. 451-462.

ZHANG, J., AND NoZAKI, Y., 1996, Rare earth elements and yttrium in seawater: ICP-MS determinations in the East Caroline, Coral Sea, and South Fiji basins of the western South Pacific Ocean: Geochimica et Cosmochimica Acta, v. 60, p. 4631-4644.

Ziegler, P.A., 2004, Europe: Permian to Recent evolution, in Selley, R.C., Cocks, L.R., and Plimer, I.R., eds., The Encyclopedia of Geology: Amsterdam, Elsevier, p. $102-125$.

Received 16 March 2011; accepted 13 July 2012. 